\title{
Phanerozoic Quartz Arenite Formation and Sequence-Analytical Patterns: Indirectly Relating to Major Impacting and Super Plume Volcanism, Jordan, Arabian Plate
}

\author{
Werner Schneider ${ }^{1}$, Elias Salameh ${ }^{2}$ \\ ${ }^{1}$ Formerly Technical University of Braunschweig, Braunschweig, Germany \\ ${ }^{2}$ University of Jordan, Amman, Jordan \\ Email: salameli@ju.edu.jo
}

How to cite this paper: Schneider, W. and Salameh, E. (2020) Phanerozoic Quartz Arenite Formation and Sequence-Analytical Patterns: Indirectly Relating to Major Impacting and Super Plume Volcanism, Jordan, Arabian Plate Open Journal of Geology, 10, 13-52.

https://doi.org/10.4236/ojg.2020.101002

Received: November 28, 2019

Accepted: January 4, 2020

Published: January 7, 2020

Copyright $\odot 2020$ by author(s) and Scientific Research Publishing Inc. This work is licensed under the Creative Commons Attribution International License (CC BY 4.0).

http://creativecommons.org/licenses/by/4.0/

cC) (i) Open Access

\begin{abstract}
This paper deals with indirect effects of major impacting throughout the Early Paleozoic resp. with those of super plume activity during the Early Cretaceous, both applied to the siliciclastic series of Jordan deposited on the Arabian Platform, Arabian Plate. Its focus is mainly directed on gases released by both processes $\left(\mathrm{CO}_{2}, \mathrm{SO}_{2}, \mathrm{NO}_{\mathrm{x}}, \mathrm{HCl}, \mathrm{HF}\right)$ and the relating acids, challenged by experiments and microscopic analysis of grain mounts and thin sections that reveal chemical instability of quartz and ultrastable heavy minerals (i.e. tourmaline) under high acidity $(\mathrm{pH}<4)$. Jordan located on the northwestern edge of the stable Arabian Platform between the Arabian-Nubian Shield as source area and the Tethys Seaway, which represented throughout the Phanerozoic a remarkably "sensitive depositional environment" documented by Cruziana Ichnofacies-bearing, even thin pelite layers, intercalating the siliciclastic braid plains/braid plain deltas during the Early Paleozoic resp. by fossil-bearing Tethys incursions during the Early Cretaceous. All quartz arenites (95\% - 100\% quartz) analyzed exhibit an enormous loss of primary mineral assemblages of hinterland source rocks (mainly granite, granodiorite, metamorphics). The heavy mineral composition (zircon, tourmaline, rutile, anatase and brookite) varies to a high extent quantitively across architectural elements, lithofacies and formations at all, reflecting manifold reworking and resedimentation. Tourmaline shows strong progressive "hack sawing" through Cambrian/Lower Ordovician suites; angular and corroded quartz grains contrast the high compositional maturity despite long transport affection. Kaolinite dominates the clay-fraction throughout the Phanerozoic and became transformed to dickite as neoformation and cement replacing quartz! by increasing burial depth below $2000 \mathrm{~m}\left(\mathrm{~T}=85^{\circ} \mathrm{C}-90^{\circ} \mathrm{C}\right)$. According to
\end{abstract}


Lopatin's Time/Temperatur-Index the Lower Cambrian reached the onset of hydrocarbon generation (liquid window) during the Lower Early Cretaceous. Unstable heavy minerals (apatite, garnet, hornblende, epidote, zoisite/clinozoisite) are generally absent in quartz arenites while in arkosic sandstones of marine environment carbonate cement and primary clay minerals (illite) provide conservation. As known since the eighties, the K/T-event's indirect effects had global influence on Earth's surface sediments and atmospheric chemistry by wildfires, hot whirl storms, acidic "sturz rain", dust, soot, darkness, loss of photosynthesis, toxic metals, gases and relating acids. All of them are here concerned and applied to major impacting throughout the Early Paleozoic using the impact data of Price (2001); while superplume volcanism during Cretaceous led to the opening of the South Atlantic accompanied by the cyclic outflow of the Paraña/Etendeka Flood Basalts and relating gases in a gigantic scale (137 - 127 Ma). Assuming that the gases cause similar global effects on Earth's surface sediments, an according result may be expected in form of quartz arenites and their sequence-analytical patterns (cyclic SBs, MFSs).

\section{Keywords}

Interrelationship, Chronostratigraphic and Lithostratigraphic b., Sequence-Analysis (SB, MFS), Major Impacting and Super Plume Volcanism (Gases!), Mass Extinction, Plate Tectonics, Diagenesis, Quartz Arenite Early Paleozoic and Early Cretaceous, Jordanian Platform, Arabian Plate (Correlations)

\section{Introduction}

Quartz arenite of first cycle origin (95\% - 100\% quartz) has been relatively rarely encountered throughout the Phanerozoic [2] [3] [4] [5].

Its genesis, in combination with kaolinite neoformation [6] [7] [8] [9], has been predominantly interpreted as by chemical weathering, mostly under warm humid climate (pH: 5 - 6) and by diagenetic processes like intrastratal solution [10] [11] [12] [13], thereby underlying qualitative/quantitative reduction of the source areas' primary mineral content.

There seems a general agreement among insiders that the agents mentioned above, do not only dissolve so-called "unstable" and "stable" heavy minerals, but may also attack or partially dissolve "ultra-stable heavies", the latter by effects of hydrothermal pore water under increasing burial depth (Figure 1(A)), whereby carbonate cement and clayey matrix would commonly retard such progressive corrosion.

Undoubtedly, in such cases the interpretation of source areas by using heavy minerals for provenance analysis becomes rather delicate or even useless.

However, there is evidence by the KPB-event (Chicxclub Crater, Yucatan,

"Neo-catastrophism is simply an expression of the "facts in questions", not an ideology nor a peculiar scientific doctrine of "Geological Philosophy". Otto Heinrich Schindewolf, Paleontologist [1]. 

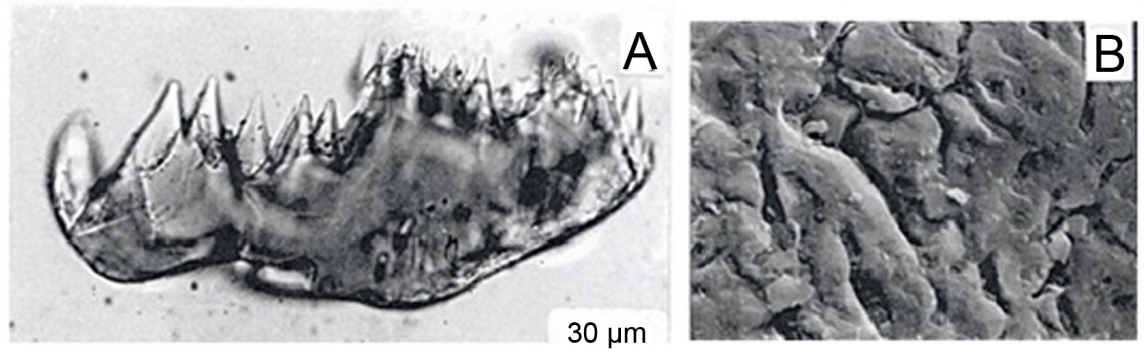

Figure 1. (A) Tourmaline grain from quartz arenite, Umm Ishrin F., Upper Cambrian. Strong dissolution patterns of "hack saw" termination, optical orientation not clear. Grain mount photograph, parallel polars [14]; (B) Corroded surface ("dissolution channels") of a quartz grain in uppermost Maastrichtian quartz arenite from Uhry "glass sand" pit/North Germany. Scanning microscopy, additional unpubl. Report relating to [21].

Mexico: $\sim 65 \mathrm{Ma}$ ) that overwhelming "sturz rain" initiated by a major impact owning high temperature and extreme acidity $(\mathrm{pH}<4)$, has global effect on Earth's atmosphere and surface [15] [16] [17] [18].

Calculations tell of some several billion tons of such acid precipitation by an impact.

The extreme high acidity of hot "sturz rain" primarily relates to the enormous impact energy causing the disintegration of $\mathrm{N}_{2}$ and $\mathrm{O}_{2}$ molecules of the atmosphere to react generating nitric oxides $\left(\mathrm{NO}_{\mathrm{x}}\right)$ in connection with hot whirl-storms and more or less global precipitation of even boiling water. Their reaction with water generates nitrous acid $\left(\mathrm{HNO}_{2}\right)$ and nitric acid $\left(\mathrm{HNO}_{3}\right)$. The same reactions concern other relevant gases like $\mathrm{CO}_{2} \rightarrow$ carbonic acid $\left(\mathrm{H}_{2} \mathrm{CO}_{3}\right), \mathrm{SO}_{2} \rightarrow$ sulfuric acid $\left(\mathrm{H}_{2} \mathrm{SO}_{3} / \mathrm{H}_{2} \mathrm{SO}_{4}\right)$, and both $\mathrm{HF} \rightarrow$ fluoric acid and $\mathrm{HCl} \rightarrow$ chloric acid providing by their mixture $\mathrm{pH}$-values $<4$ depending on crater distance [9] [15] [16] [17] [18].

In case of the KPB-event, the impactor interacted with the atmosphere $(78.9 \%$ $\mathrm{N}_{2}, 20 \% \mathrm{O}_{2}, 1 \% \mathrm{CO}_{2}$ ), with a seawater column of $\sim 100 \mathrm{~m}(\mathrm{C} 1, \mathrm{~N}, \mathrm{~S}, \mathrm{~F})$, some $2900 \mathrm{~m}$ interstratified carbonate and sulfate rocks $\left(\mathrm{CO}_{2}, \mathrm{SO}_{2}\right)$, and finally with a $\sim 30 \mathrm{~km}$ granite sequence of the basement (C1, N, S, F) [17] (Table 1). Figure 2 shows the basic mineralogical data of the KPB-event at Agosta, Spain exposing kaolinite boundary clay and $\mathrm{C}$ and $\mathrm{O}$-isotope distribution around the extinction layer [17] [19].

Beyond that, experiments surprisingly verify that a mixture of $\mathrm{HNO}_{3}(1 / 6$ of $5 \%), \mathrm{H}_{2} \mathrm{SO}_{4}(1 / 6$ of $5 \%)$ and $\mathrm{HF}(2 / 3$ of $5 \%$ ) dealing with $200 \mathrm{ml}$ for dissolution of 10 gram of rock sample dissolve common $\beta$-quartz in order to enrich both high pressure $\mathrm{SiO}_{2}$-modifications coesite and stishovite from shock wave deformed silicate rocks inferring that $\beta$-quartz and other silicates of different rock types are dissolvable under the high acidity applied [20].

Reconfirming Stoeffler's experiments in nature, one of our master students (G. Ramme) found, by additional investigations to his Diploma Thesis [21], highly corroded quartz grains in upper most Maastrichtian quartz arenites at Uhry, North Germany (Figure 1(B)), deposited in both rim synclines of a salt 
Table 1. Relevant element concentrations in seawater and granites in ppm [9].

\begin{tabular}{ccccc}
\hline Parameter/Medium & CL & N & S & F \\
\hline Sea water & 18,800 & 150 & 905 & 1.3 \\
Granite & 200 & 20 & 300 & 800 \\
\hline
\end{tabular}

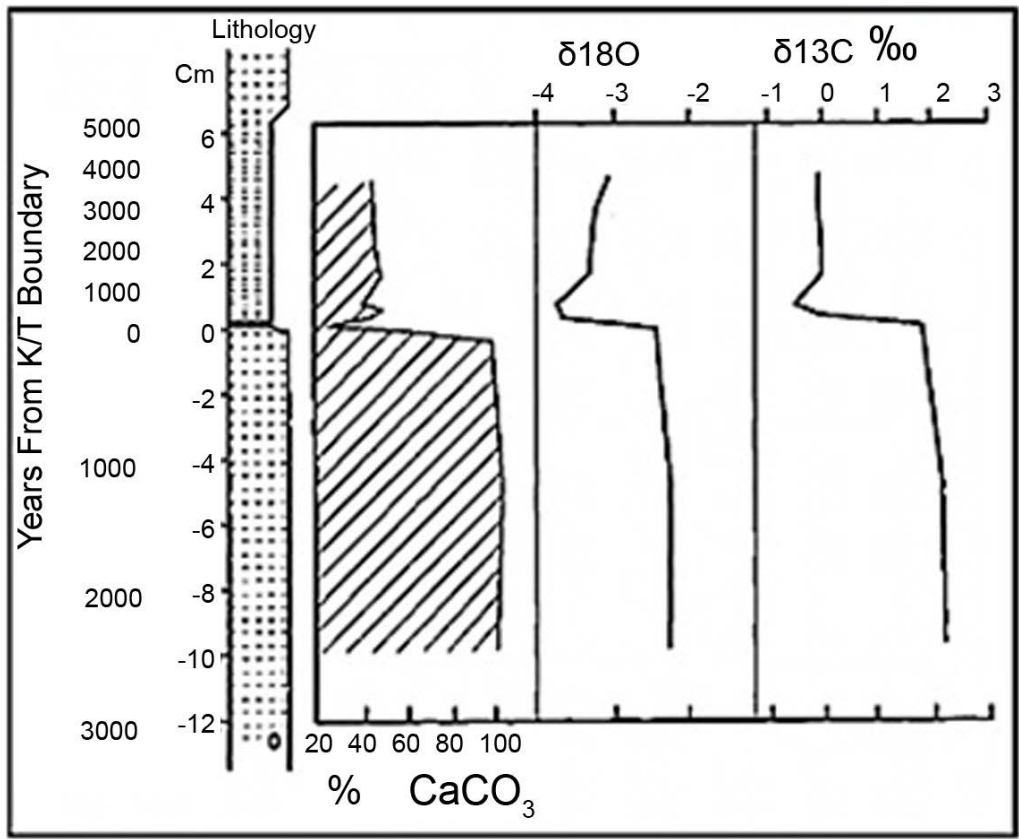

Figure 2. Profile of the K/T-b. at Agost, Spain. Kaolinite boundary clay containing globally more or less elements of the Platin-group, glass spherules, shocked quartz and zircon, soot of global wild fires, isotope anomalies of C and O [17] [19].

diapir in trap position. We relate this evidence of high acidity to the KPB-event (65 Ma) and/or to the later Popigai/Chesapeake-events (36.5/36.1 Ma) shortly prior to the Eocene/Oligocene b. (33.75 Ma), see for comparison [22]. Pre-KPB plume effects cannot be excluded.

Furthermore, toxic metals (Al, Be, $\mathrm{Pb}, \mathrm{Hg}, \mathrm{Cd}, \mathrm{Ti}, \mathrm{Cu}, \mathrm{Fe}, \mathrm{Ni}, \mathrm{Mn}, \mathrm{Sr}, \mathrm{V}, \mathrm{U}$ and $\mathrm{Zn}$ ) frequently substituted in common minerals of relevant rocks and soils are released in soluble form for subsequent toxic reaction [18]. Thus, i.e. $\mathrm{Fe}^{3+}$ may be washed out from clastic deposits to lose its reddish/brownish color (red beds) for later re-precipitation.

Hence, the concept submitted tells: if such highly acid solutions initiated by major impacting volcanism work in situ through a certain timespan in a suitable geologic setting of arkosic/subarkosic sandstones, mature first cycle quartz arenites may be the product, in paragenesis with kaolinite neoformation.

In order to have a solid ground for testing the temporal coincidence of impact age with sedimentary implications like formation boundaries, sequence-analytical patterns (SB, MFS), architectural elements, lithofacies, and mineral content, we apply the major impact data of Price [23] as we did in a former pilot study [24] in Jordan [24]. 
Price recovered such convulsive events by using the plate tectonic parameters of abrupt change of both direction and speed of plates' motion. He applied the ATLAS-SYSTEM (version 3.3) developed by A. Smith and co-workers, Cambridge University, England as mapping global reconstruction system for P.C. in order to design maps and tracks of continental bodies or individual islands through various Phanerozoic episodes. Figure 3 shows the tracks of Fennoscandia (A) and of Hawaii (B) during the early Paleozoic and Figure 4 follows the tracks of South America (A) and Africa (B) during the Lower Cretaceous.

Thus, the ATLAS-SYSTEM represents a map-making package comprising EULER-rotations and a variety of utilities for creating paleogeographic reconstructions for the last $600 \mathrm{Ma}$. It provides estimates of the past position of present-day shaped coastlines.

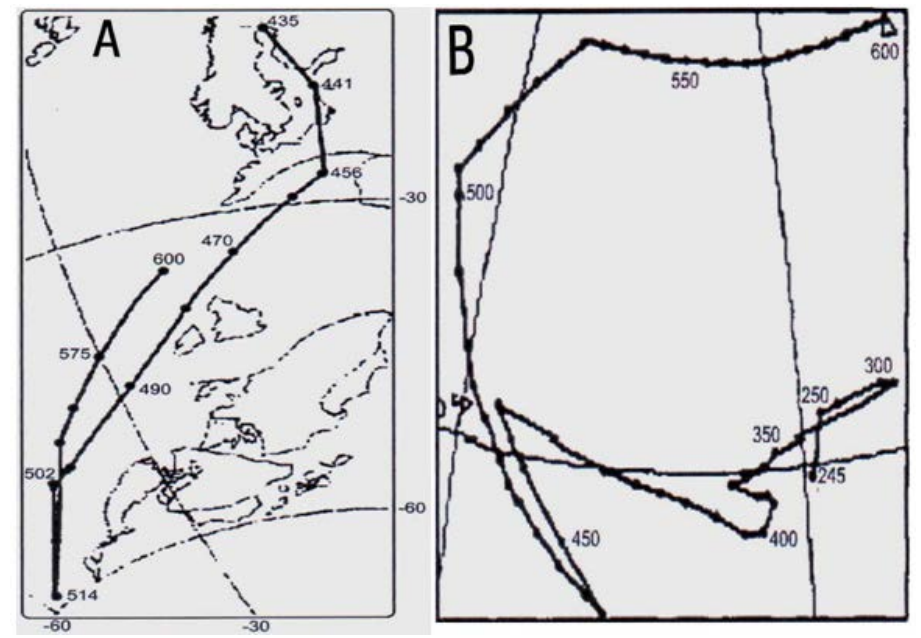

Figure 3. Tracks of Fennoscandia (A) and of Hawaii (B) during the Paleozoic [23]. Significant track change indicates a major impact (see also Figure 5).
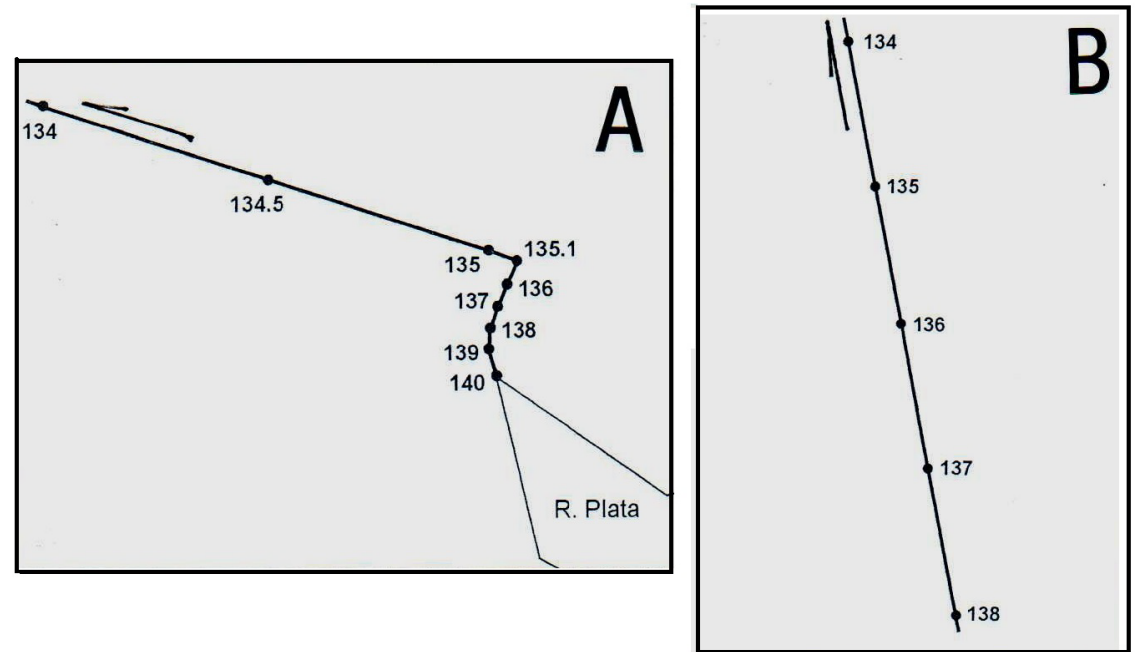

Figure 4. Tracks of South America (A) and of Africa (B) through the Jurassic- Cretaceous time-span [23]. 135.1 Ma indicate a major impact? and the beginning of flood basalt effusion (Paraña, Etendeka). 
This paper tries to check the relevance of Price's Major Impacts to quartz arenites under the aspect of indirectly initiated super-acidic "sturz rain" conditions by analyzing the following Phanerozoic quartz arenites deposited on the Arabian Platform across Jordan (Figure 5). As for mineralogic comparison, an arkosic/subarkosic sequence (Saleb F.) is added.

- Saleb F.: Lower Cambrian, arkosic/subarkosic arenite $(0-70 \mathrm{~m})$.

- Burj/White Fine Sandstone F.: Early/Middle Cambrian developed intraformationally from subarkosic to quartz arenite (max. $110 \mathrm{~m})$.

- Umm Ishrin F.: Middle/Upper Cambrian, quartz arenite (max. 110 m).

- Disi F.: Upper Cambrian/Early Ordovician Quartz arenite $(250 \mathrm{~m})$.

- Um Sahm F.: Arenig ${ }^{1}$, quartz ${ }^{2}$ arenite $(250 \mathrm{~m})$.

- Kurnub F.: Lower Cretaceous, intraformational transition from sub-arkosic to quartz arenite (upper part) $(220 \mathrm{~m})$.

Two other quartz arenite sequences of the same geological setting (Arabian Platform) as the Permo-Triassic Umm Irna F. and the Lower Triassic Ma'in/Dardur F. are intended to be possibly dealt with separately.

\section{Geologic Setting and Paleogeography}

The Arabian Plate comprises the Arabian Shield, the adjoining Arabian Platform,

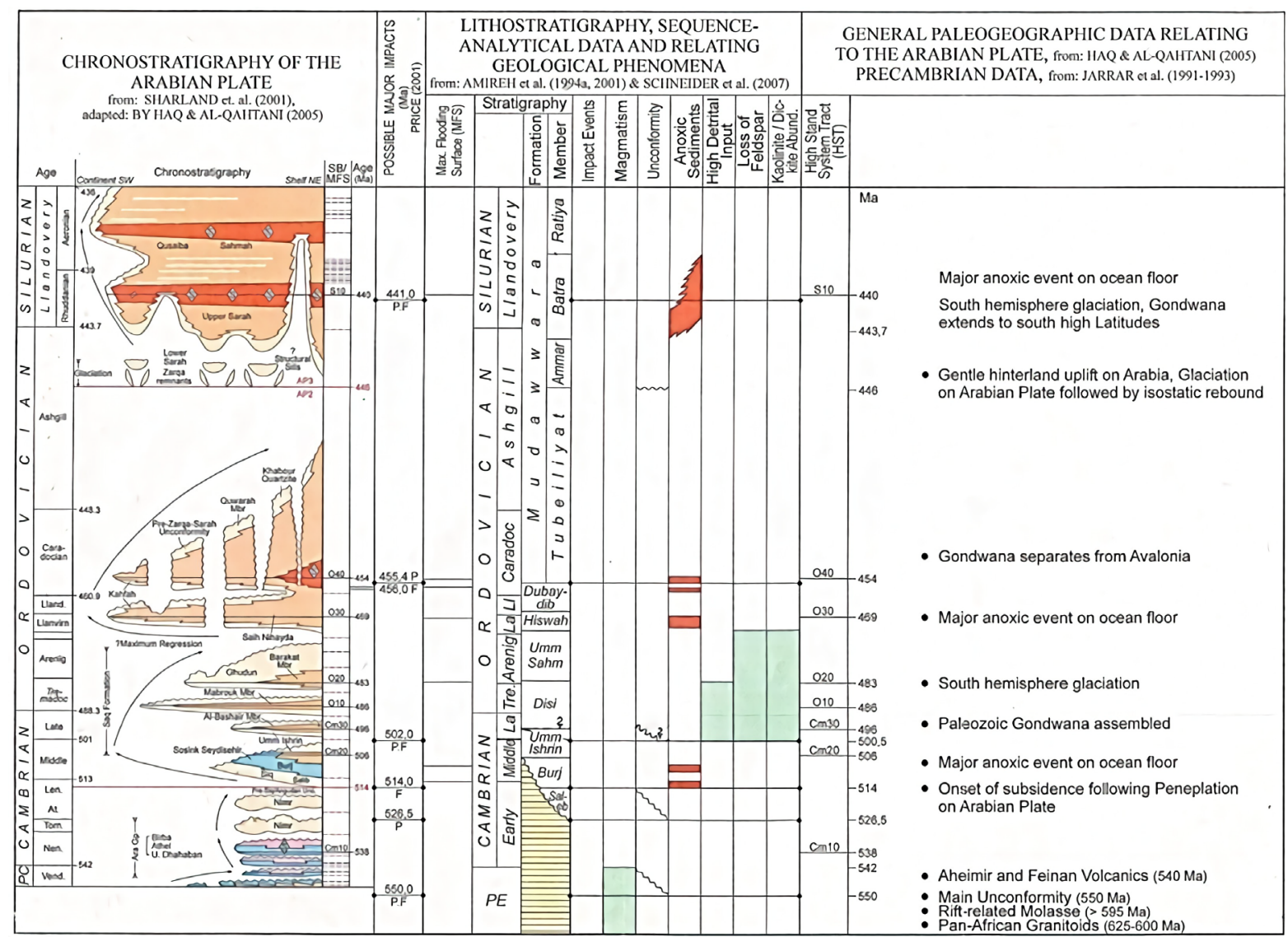

Figure 5. Chart of the Early Paleozoic for the Arabian Plate based on [30] [31] [32]. All dates and references cited are dealt with and discussed in Chapts. 2 and 3. 
and the surrounding sedimentary basins [25] [26] [27] [28] [29]. It was part of Gondwana through the Paleozoic era and developed as a result of late Proterozoic suturing of several terranes dominated by largely basic volcanism and plutonic rocks that were localized along the NE and WNW-trending basement sutures like the Najd strike slip movement (Figure 6, Figure 7).

The chronostratigraphic data relate to Sharland et al. [30], recalibrated and adapted by Haq \& Al-Qahtani [31], re-applied by Schneider et al. [32] (Figure 5, Figure 8).

In SW Jordan, as the northwestern part of the Arabian Plate, the Pan-African calc-alkali granitoids ( $625-600 \mathrm{Ma}$ ) were succeeded by the Volcano-Sedimentary Pan-African Molasse Sequence represented by the Saramuj Conglomerate (600 -

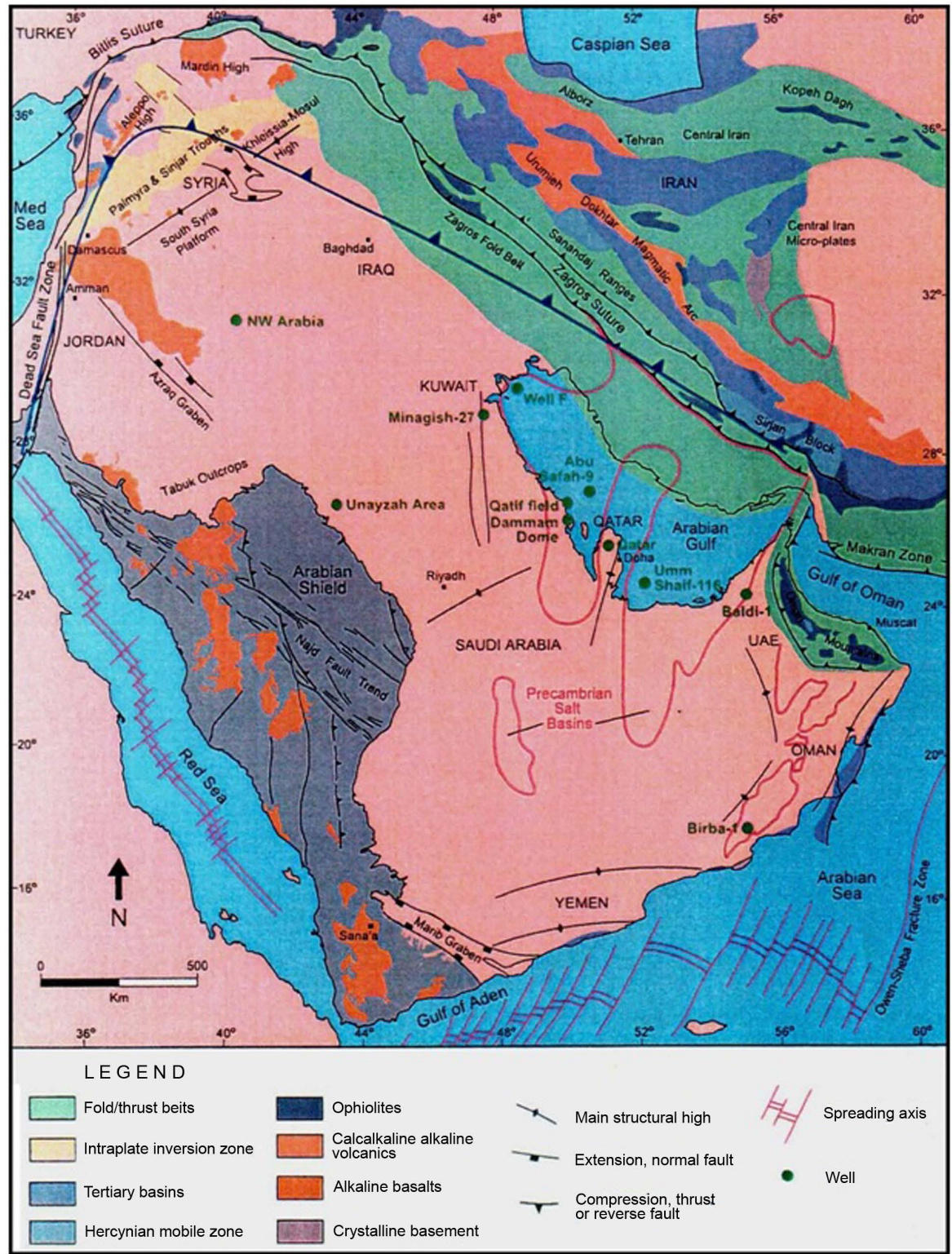

Figure 6. Major tectonic elements of the Arabian Platform and adjacent areas. Jordan is located in the northwestern part and confined by the Dead Sea fault zone [27] [28] [29]. 


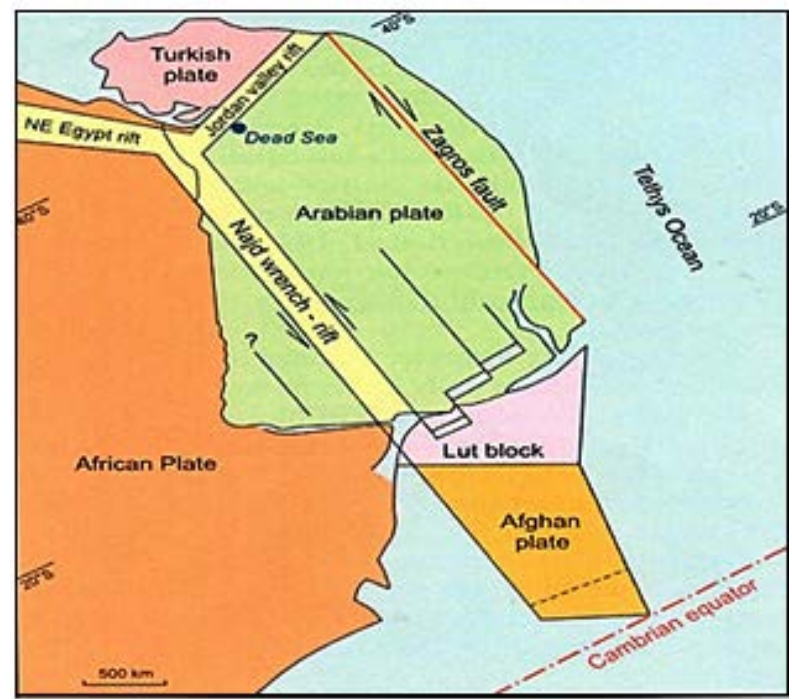

Figure 7. Arabian Infra-Cambrian Extensional System (600 - $540 \mathrm{Ma}$ ) [25] [26] [27]. Note the position of Jordan as northwestern part of the Arabian Plate and the triple junction of the Jordan Rift Valley, NE-Egypt Rift and the Najd Wrench-Rift running NW/SE.

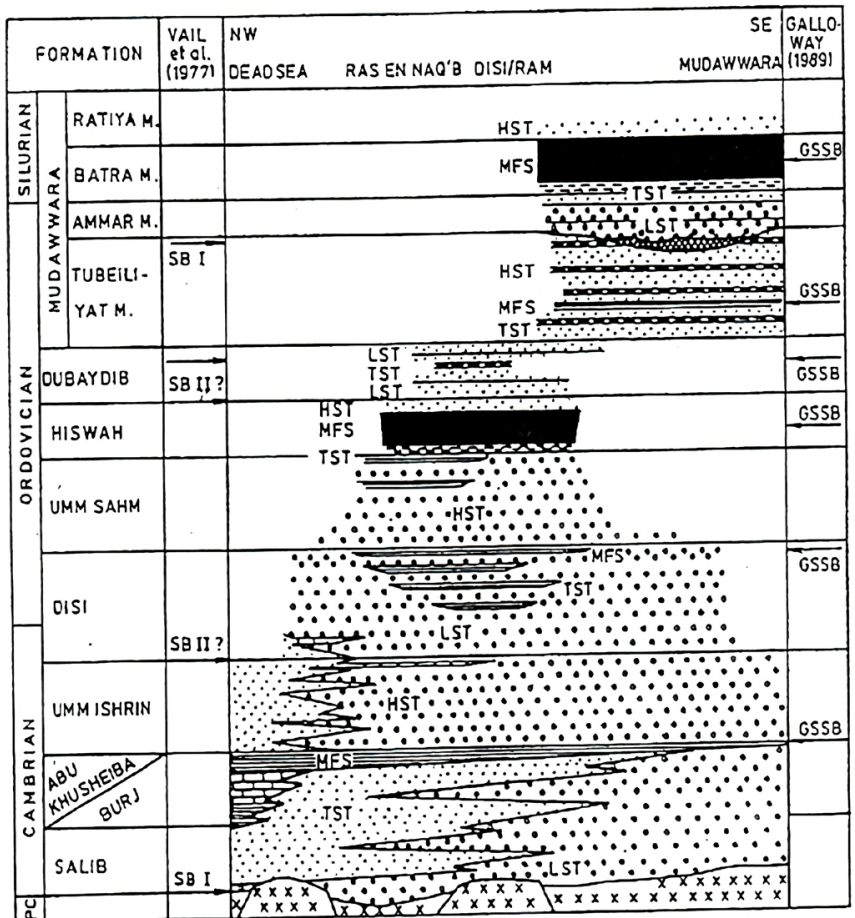

\begin{tabular}{|c|c|c|c|}
\hline & OFFSHORE & $\because \because \because 9$ & FLUVIAL I DELTAIC \\
\hline$==-1$ & TRANSITIONAL ZONE & 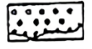 & GLACIO-FLUVIAL \\
\hline 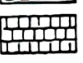 & $\begin{array}{l}\text { FORESHORE/ SHOREFACE } \\
\text { CARBONATE FACIES }\end{array}$ & 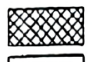 & LOESS \\
\hline $\bar{E}$ & $\begin{array}{l}\text { FORESHORE/SHOREFACE } \\
\text { PELITE-SANDFACIES }\end{array}$ & 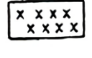 & PRECAMBRIAN BASEMENi \\
\hline$\because \because \because$ & $\begin{array}{l}\text { FORESHORE I SHOREFACE } \\
\text { SANDFACIES }\end{array}$ & & \\
\hline
\end{tabular}

Figure 8. Sequence-analytical model of the Early Paleozoic Systems of Jordan. SB Sequence Boundary, GSSB Genetic Stratigraphic Sequence Boundary, MFS Maximum Flooding Surface, LST Low Stand Systems Tract, TST Transgressive Systems Tract, HST High Stand Systems Tract [32]. 
$595 \mathrm{Ma})$, [33] [34] [35]. After several phases the Pan-African Mountain Building completed the Gondwana formation around the Precambrian/Cambrian b. (550 $542 \mathrm{Ma}$ ) (Figure 5).

Gondwana's central parts were dominated by late Proterozoic Island complexes built up of ophiolites and basaltic/andesitic volcanics intruded by granitoids and accompanied by metamorphics [27] [28]. These rock suites provided the siliciclastics of the complete early Paleozoic sequences of Jordan $(\sim 1700 \mathrm{~m})$ and finally almost all Phanerozoic clastics until Cretaceous.

Thus, the "Jordanian Platform" represented throughout the Phanerozoic a sensitive transition zone between the stable Arabian Shield and the Tethys Seaway, where predominantly a warm humid climate and eustasy were the most controlling factors in regard to paleogeography, architectural sedimentary elements, and clastics' mineral assemblages [5] [30] [31] [32]. These siliciclastic series mostly reveal second and third order sequences separated by regional unconformities/hiatus where stratigraphic b. are mainly related to Sequence b. (SB) and Maximum Flooding Surface (MFS) (Figure 5, Figure 8).

The early Cambrian uplift caused wide-spread erosion during the block faulting Molasse-Phase of the Pan-African Mountain-Building and was followed by proximal alluvial fans of the Saleb F. (526.5 - $514 \mathrm{Ma),} \mathrm{[32]} \mathrm{[33]} \mathrm{[34]} \mathrm{[35]} \mathrm{[36].}$ The important Pre-Siq/Angudan Unconformity (SB) is overlain by the Burj F. composed of interstratified marine carbonates and the braid plain deltaic White Fine Sandstone F. of Middle Cambrian age (514 - $506 \mathrm{Ma}$ ). Anoxic blackshale represents a MFS as a maximum Tethys ingression due to global sea level rise [30] [31] [32] (Figure 9).

After the Tethys regression increasing detrital influx provided northward prograding sand flats of the Umm Ishrin F. (Middle/Late Cambrian) rarely invaded by Cruziana-bearing shale where a monotonous downstream accretion (DA) dominated in a High-Stand-System-Tract (506 - 505.5 - 496 Ma), [32] [36] [37].

The Umm Ishrin/Disi F. b. is a "problematic fact in question" discussed as hiatus/unconformity. This boundary marks an abrupt change from low/medium energy bedded DA-macroforms to thick-bedded high energy DA-macroforms of massive sedimentary load building up some 10 - 12 fining upward sequences of the Disi F. [32] [38] (Figure 10(A), Figure 10(B)).

That demands a dramatic change of atmospheric conditions ("sturz rain"-events). The DA-macroforms are frequently overturned and own flow-structures, deposited under critical transport velocity and accompanied by isolated well rounded scattered quartz pebbles (up to $12 \mathrm{~cm}^{\Phi}$ ) and lag-deposits at the base of fining upward sequences (Figure 11).

Shales intercalated in the middle/upper part of the Disi F. bear Cruclana furcifera and other Cr. ichnofacies of early Ordovician age representing a MFS ( 486 Ma), [38] [39] [40].

So it seems probable that the base of the Disi F, has to be set into the Upper Cambrian, or even coinciding with the Middle/Upper Cambrian b. (501 Ma). 


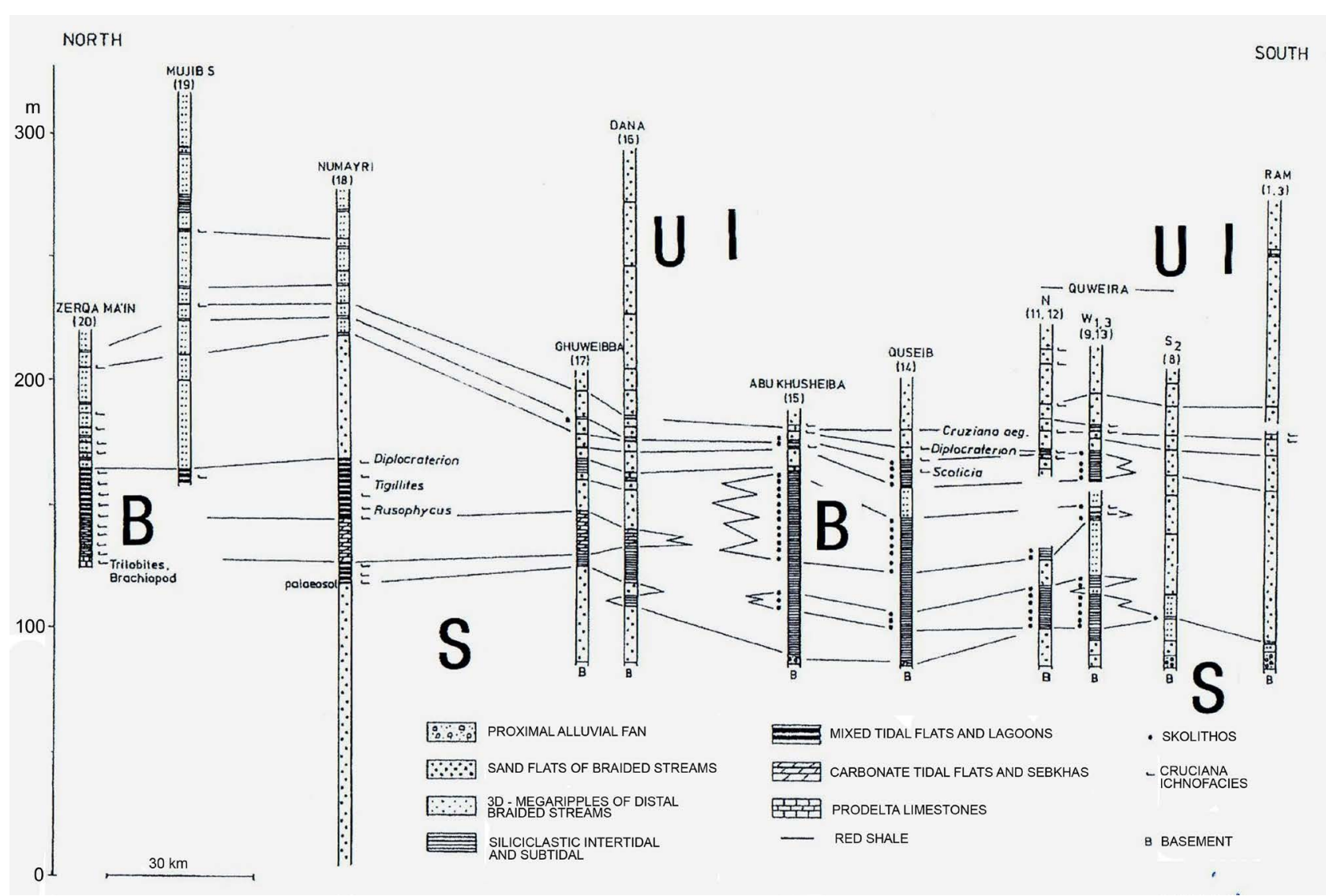

Figure 9. Cambrian F. in SW-Jordan: Sedimentary Environments, Lithofacies distribution and Ichnofacies correlation, S Saleb F., B Burj F., UI Umm Ishrin F [32] [36] [37].
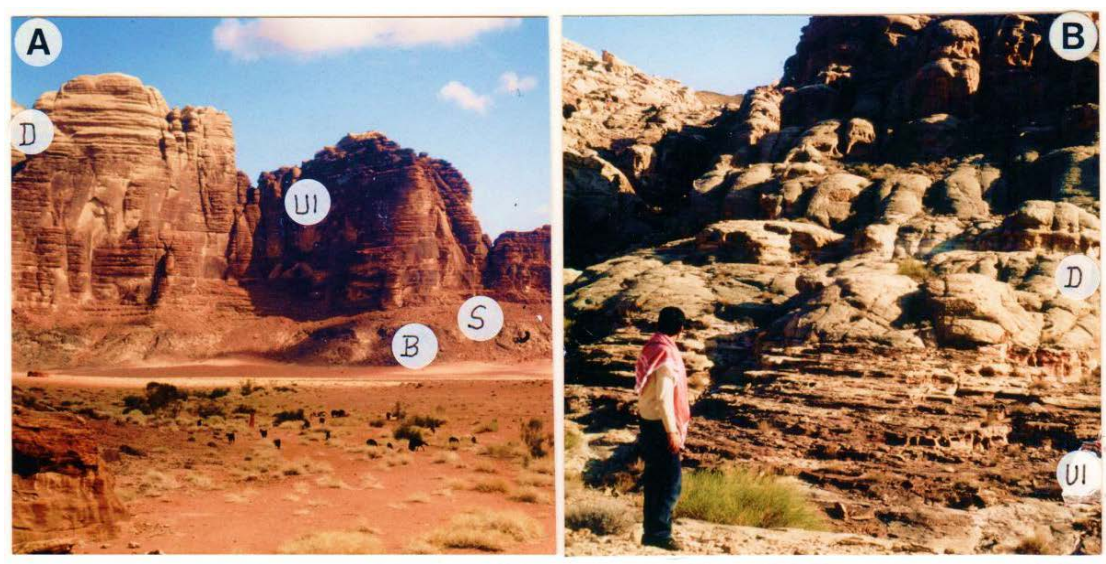

Figure 10. Transitional zone Umm Ishrin/Disi F. (Middle/Upper Cambrian?). (A) Classic section at Wadi Ram: B Crystalline basement, S Saleb F., UI Umm Ishrin F., D Disi F. (B) Problematic transition zone Umm Ishrin (red)/Disi F. (white): change of transport energy and architectural elements. Wadi Khubar/north of Quweira, (Hiatus?).

At the Disi/Umm Sahm F. b. (483 Ma) a slight sea level rise transferred the fluvial dominated braid plains of the Disi F. towards a fluvial dominated braid plain delta bearing marine ichnofauna and intertidal/mixed flats, so becoming increasingly marine [32] [38] [39]. 


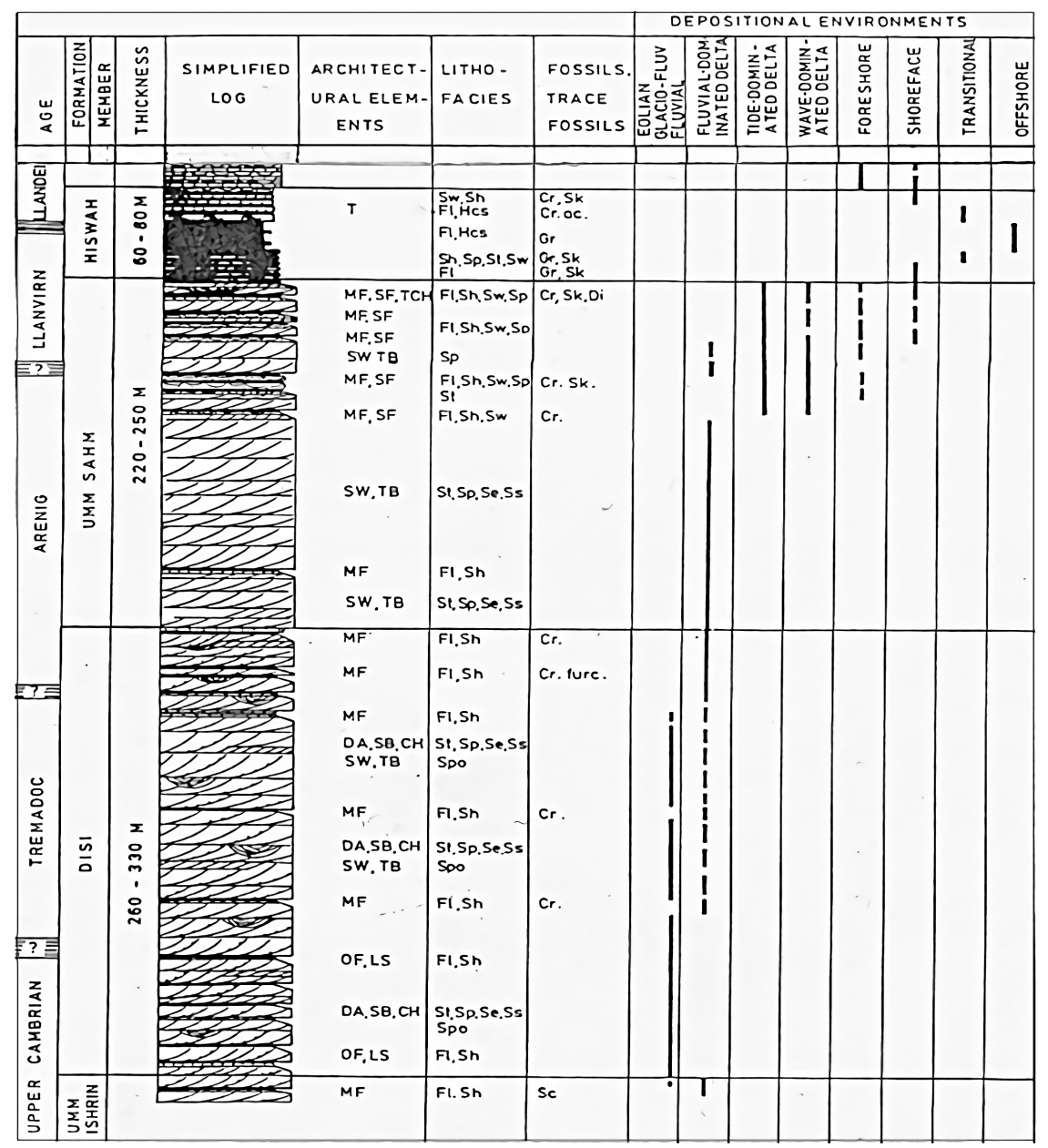

Figure 11. Section Upper Cambrian (Disi F.) - Tremadoc (Disi F.) -Arenig (Disi/Umm Sahm F.) -Llanvirn (Umm Sahm/Hiswah F.): Architectural elements, lithostratigraphy, tracefossils and depositional environments [32] [38].

The Umm Sahm/Hiswah F. b. ( 474 Ma) coincides with a SB on the Arabian Plate and the onset of south hemisphere glaciation. It is followed by an important transgression that developed from shore face to off shore environment represented by graptolite-bearing black shales (MFS: $469 \mathrm{Ma}$ ), as an anoxic event on ocean floor (Figure 8).

Geologic Setting and Paleogeography of the Lower Cretaceous (Kurnub Group)

This sequence crops out east of the Jordan Rift shoulder between Ras en Naqab in the south and the Zerqa River in the north [41].

During the Lower Cretaceous (145.5 Ma), also exposing quartz arenite across Jordan, the general Paleogeography between the Arabian/Nubian Shield and the Tethys Seaway remained more or less similar like during the early Paleozoic.

The Near East was affected from the Jurassic/Cretaceous b. until the Hauterivian by orogenic movements accompanied by volcanic activity across the Levant that left a hiatus with paleosol in North Jordan overlain with quartz arenites [41] [42] (Figures 12-14). 


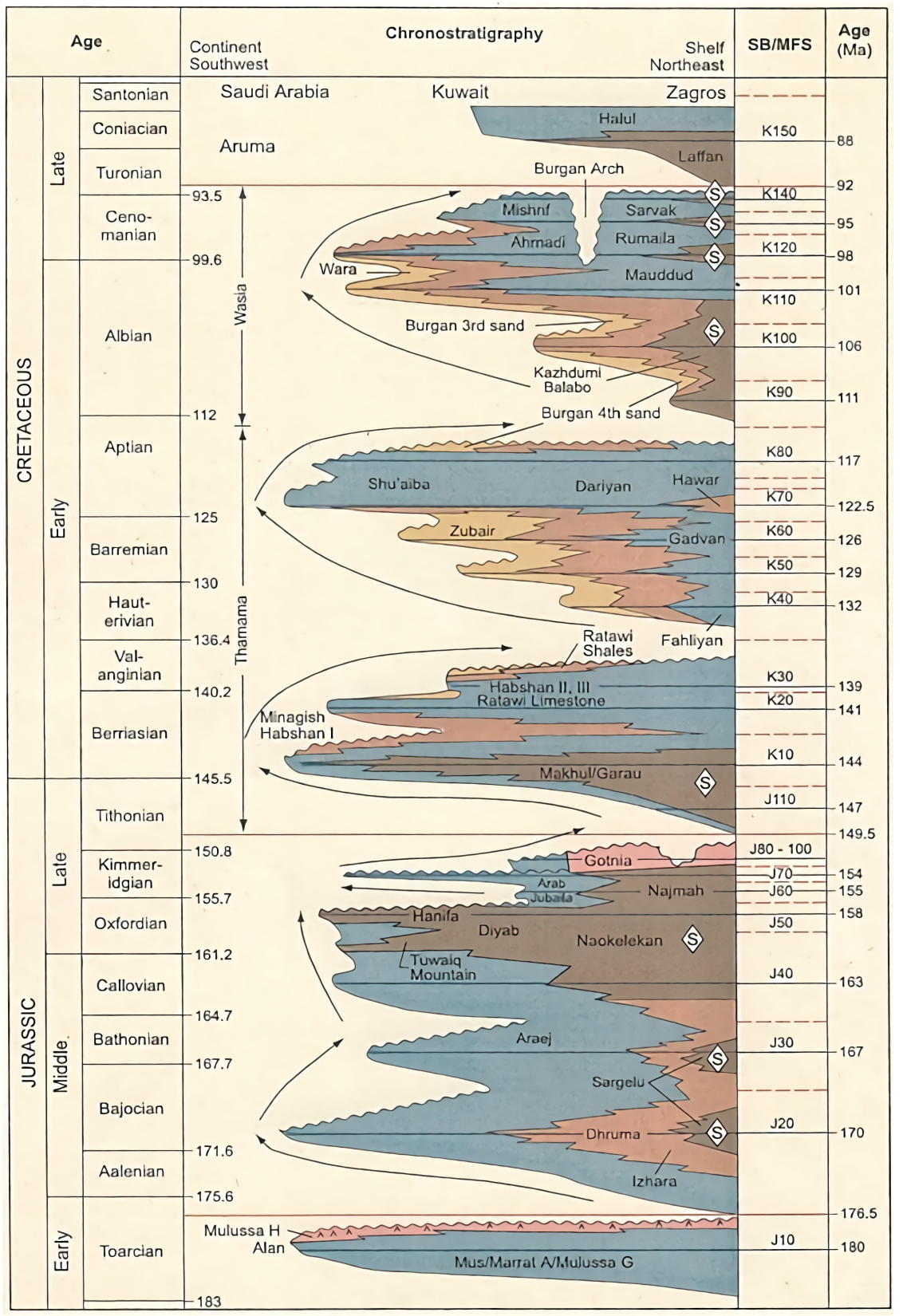

Figure 12. Schematic chart of the Early Cretaceous interval after Sharland et al. (2001) and Haq \& Al-Qahtani (2005) [30] [31]. Note SBs 149.5 Ma, 136.4 Ma (base Hauterivian) and $112 \mathrm{Ma}$ (Aptian/Albian b.).

From time to time marine incursions occurred onto the Jordanian platform. However, most of the study area was part of proximal to distal braid plains whose hinterland provided up to $220 \mathrm{~m}$ of siliciclastics through the time-span Hauterivian until the Lower/Upper Cretaceous b (99 Ma).

While North Jordan exposes three main transgressive incursions onto the platform that relate to global sea level rise, the fining upward cycles of quartz arenite in central and south Jordan remained without marine influence (Figure 14). In areas of marine influence the Kurnub Group reveals a highly differentiated 


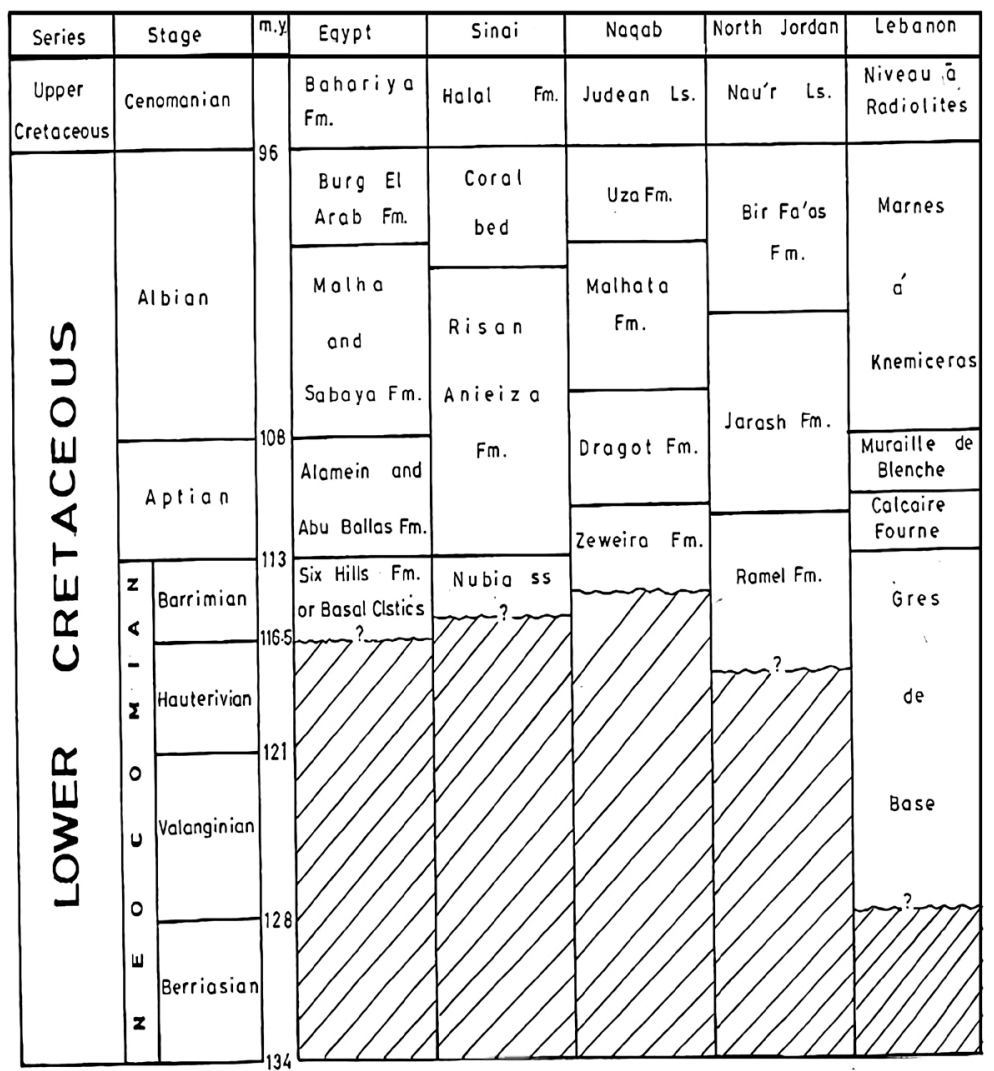

Figure 13. Stratigraphic units of Early Cretaceous (Kurnub Group) in the Near East. The hiatus between Tithonian and Berriasian/Barremian meets mountain building (Inner Hellenic Suture) in Greece and widespread paleosol formation [41] [42].
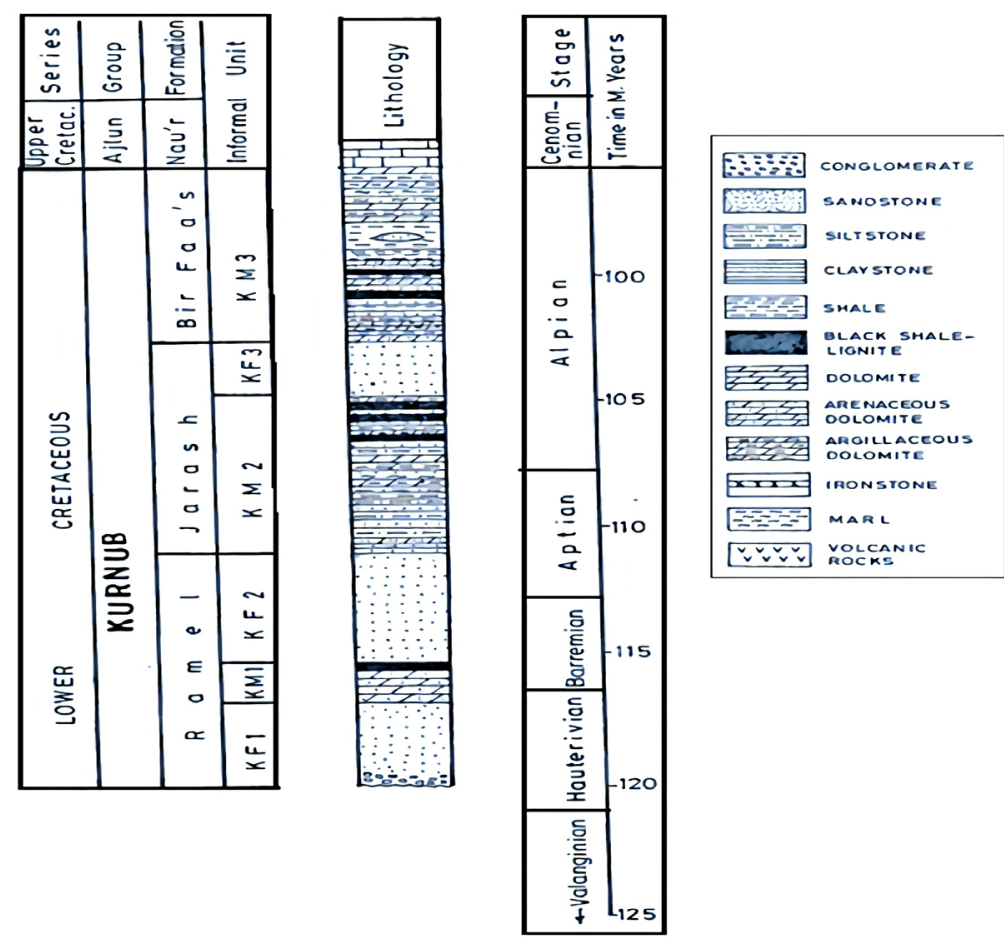

Figure 14. Generalized lithostratigraphy of the Kurnub Group in Jordan [41]. 
spectrum of various sedimentary environments of interbedded shelf carbonates, tidal flats, coastal swamps and lignites [41].

The source rock composition of the Nubian/Arabian hinterland has to be interpreted, according to heavy mineral analysis, as similar like that of the early Paleozoic Series.

\section{Sequence-Analytical Data, Mineral Assemblage, Their Implication to Major Impacting and Mass Extinction (Plates 1-3)}

Price [23] applied his track dates of plates for the time-span 600 - $250 \mathrm{Ma}$ to both Fennoscandia (Figure 3(A)) and Hawaii/Pacific (Figure 3(B)). Most of sudden changes (direction, velocity) of both plates reveal high coincidence in time. One difference concerns the 526.4 Ma-event of Hawaii to be correlated with the St. David/Merioneth b. (523 Ma) and the $514 \mathrm{Ma}$-event of Fennoscandia to be correlated with the Maentwrog/Dolgellian b. (514 Ma). As he stresses, both references are of equal validity. Since dating moves in a process of refinement (recalibration), he is aware of age error bars of up to $5 \%$. However, most of the relevant early Paleozoic track changes (550, 502, 456/455 441 Ma) coincide with major stratigraphic boundaries (Figure 5, Figure 8).

Thus, he does not hesitate to conclude that major impacts were controlling, driving or even determining the Geologic History throughout the early Paleozoic.

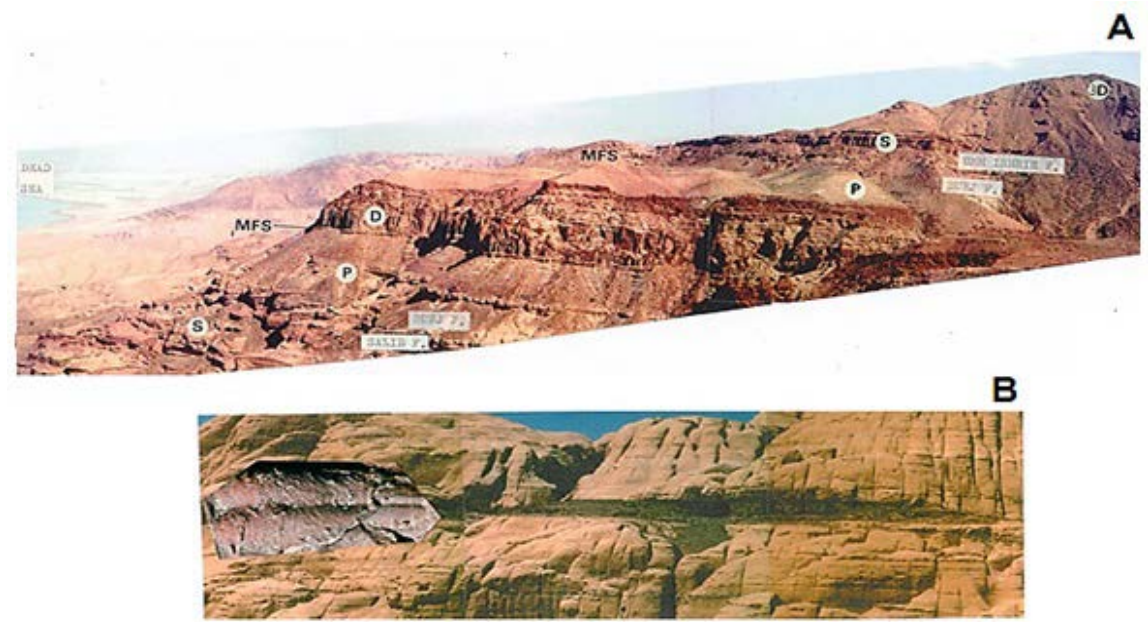

Plate 1. Landscape scenarios of Phanerozoic Arenite Formations, Jordan. (A) Cambrian section located in the Numeira area (Southeastern end of the Dead Sea). Lower part: lower Cambrian (Saleb F.): fluvial sand flats (S). Middle part: Middle Cambrian (Burj F.): composed of two marine ingression (pelites $\mathrm{P}$ ), Mixed tidal flats bearing Rusophycus, intertidal and lagoonal pelites, massive and slightly bedded intertidal and Sabkha dolomites (D) correlates with worldwide sea level rise. Both MFSs are situated in the top part of the pelites, Upper part: (Upper Cambrian: Umm Ishrin F.) fluvial sandflats, 3 D megaripple facies and DA elements of median transport energy. (B) Fluvial-deltaic downward accretion elements of the Disi F. (Upper Cambrian-Tremadoc), intercalated with a dark-red marine ingression by pelite-bearing Cruziana furcifera (Lower Ordovician), Disi area. South Jordan. Length of outcrop $\sim 80 \mathrm{~m}$. 

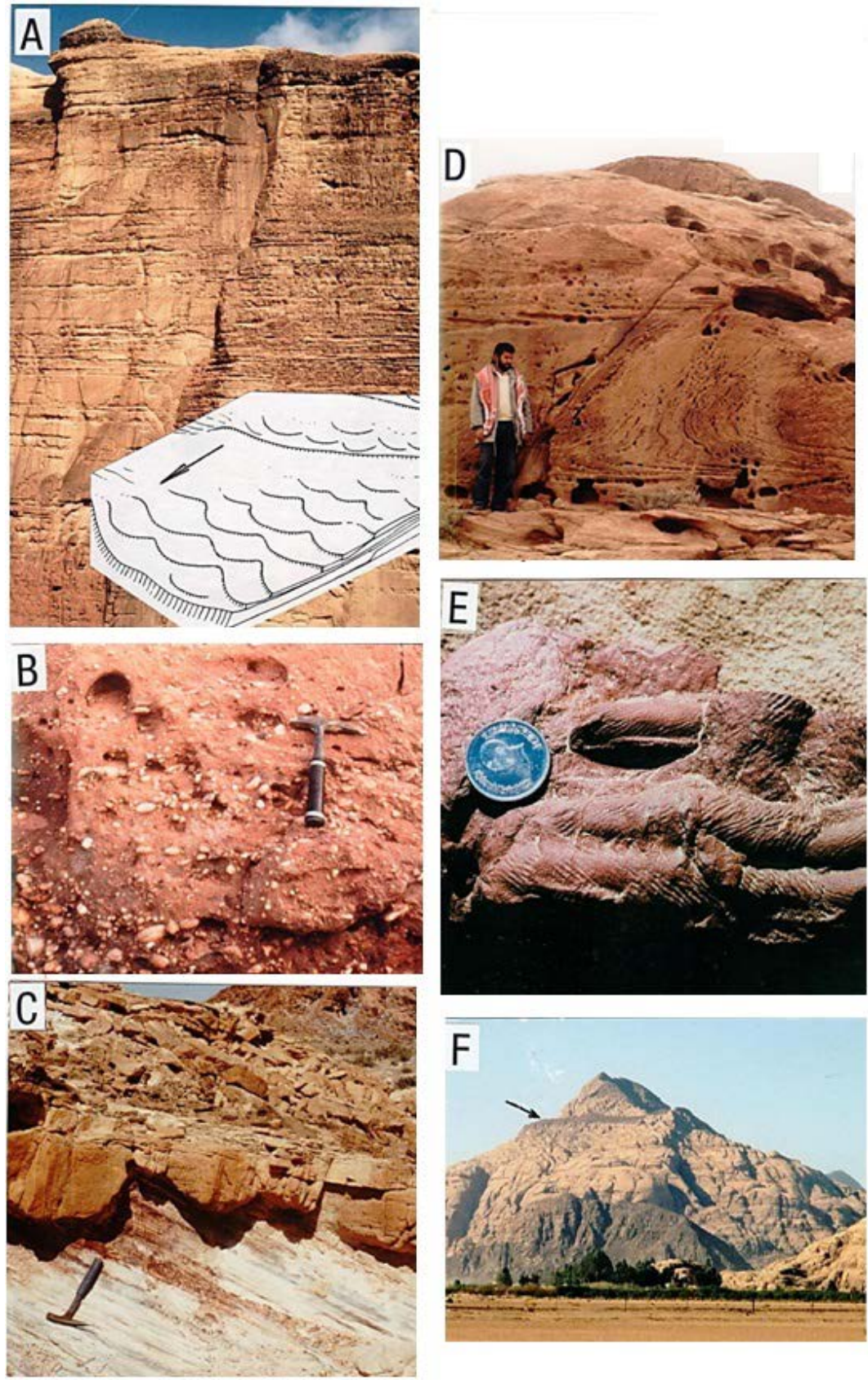

Plate 2. Architectural elements and lithofacies of Phanerozoic Quartz Arenites. (A) Fluvial downward accretion elements of moderate transport energy. Umm Ishrin F. (Upper Cambrian), section height $\sim 100$ meters, Jebel Ram. (B) Fining upward mass flow (Gms) indicating a hazardous flash-flood in the transition zone Umm Ishrin/Disi F., northern Wadi Ram. (C) Fine-grained bar sediments occupied by Scolithos-Ichnofacies dipping east northeastward. Their top portions reveal south/north-directed channel fill (St), also bearing Scolithos in the uppermost laminated part (Sh), Wadi Abu Khusheiba. (D) High transport energy-directed overturned cross bedding in the Disi F., downstream accretion braided streams, Disi area. B. Amireh. Jordan University, Amman (1986). (E) Cruziana furcifera in red marine pelites indicating Lower Ordovician age, Jebel Amud, Disi area. (F) Jebel Amud, west of Disi; below: Quartz arenite (Umm Ishrin F.), (dark) overlain with quartz arenite of the Disi F. (white) that is intercalated by a few meters thick marine dark pelite-bearing Cruziana furcifera of Lower Ordovician age (arrow). 

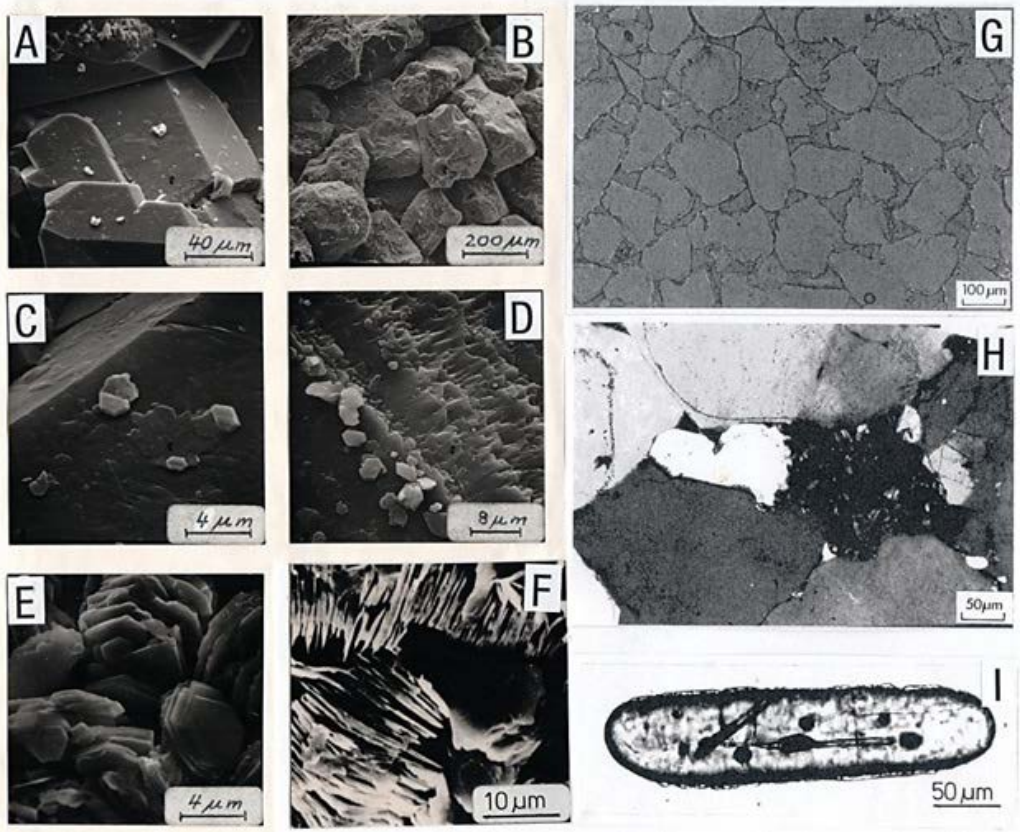

Plate 3. SEM and thin section photomicrographs of Phanerozoic Arenites. (A) Syntaxial overgrowth of quartz in quartz arenite, Umm Ishrin F., Wadi Zerqa Ma'in [50]. (B) Lower Cretaceous quartz arenite showing a porosity of $\sim 25 \%$ and poor syntaxial overgrowth. Note the angular form of quartz grains, Wadi Zerqa Ma'in [50]. (C) Epitaxy of neoformed kaolinite/dickte crystals on syntaxally overgrown quartz grain. Umm Ishrin f./Upper Cambrian, Wadi Zerqa Ma'in [50]. (D) Like (C) however, partial replacement of quartz by dickite neoformation [50]. (E) Dickite-neoformation in pore space of Umm Ishrin quartz aranite, Wadi Zerqa Ma'in [50]. (F) Dickite as seen at SEM in form of large "books" of stacked hexagonal dickite plates, Disi F., Lower Ordovician [14]. (G) Kurnub quartz arenite, porosity $25 \%-30 \%$. Note slight syntaxial overgrowth and the angular corroded quartz grains, Wadi Zerqa Ma'in [50]. (H) Quartz arenite, Umm Ishrin F./Upper Cambrian. Thin section shows syntaxial overgrowth of \pm well rounded quartz grains and kaolinite/dickite filling the porespace, Wadi Zerqa Ma'in, x nicols. (I) Zircon displaying slight overgrowth (saw fish-like) with thin euhedral faces [47]. Interpretation: in situ-dissolution and immediate re-precipitation, grain mount photograph.

Thereby, the impact site must definitely not coincide with the reference areas; however, the impact itself does influence the motion of continental masses. In case of continents' collision, sharp track changes would be destroyed. Concerning oceanic plates, a shorter residence time for tracks is to be expected caused by subduction.

In the following, chronostratigraphic age (Figure 5), sequence-analytical patterns (SBs, MFSs), major impacts (Figure 3(A), Figure 3(B), Figure 4(A), Figure 3(B)), and mass extinctions (Figure 15), [43] [44] [45] [46], are compiled in Figure 16. Most of the granulometric, mineralogic/chemical data relate to Amireh's PhD-thesis [47]: Table 2 provides the granulometric data after Folk \&Ward [48], architectural elements and lithofacies are based on Miall [49], (Table 3). Table 4 presents the light and heavy minerals from grain mounts [47] and Table 5 major and trace elements [47] of one arkosic/subarkosic arenite and five quartz arenite F. (see Introduction). 


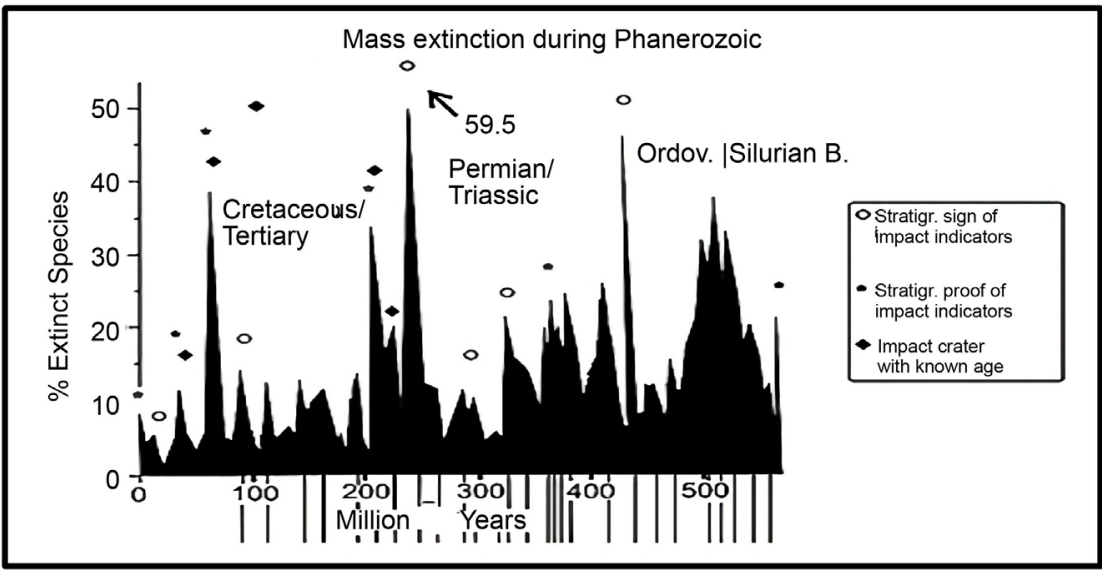

Figure 15. Mass extinction throughout the Phanerozic with stratigraphic hints on impact indicators and impact craters of known ages [17] [43] [44] [45] [46].

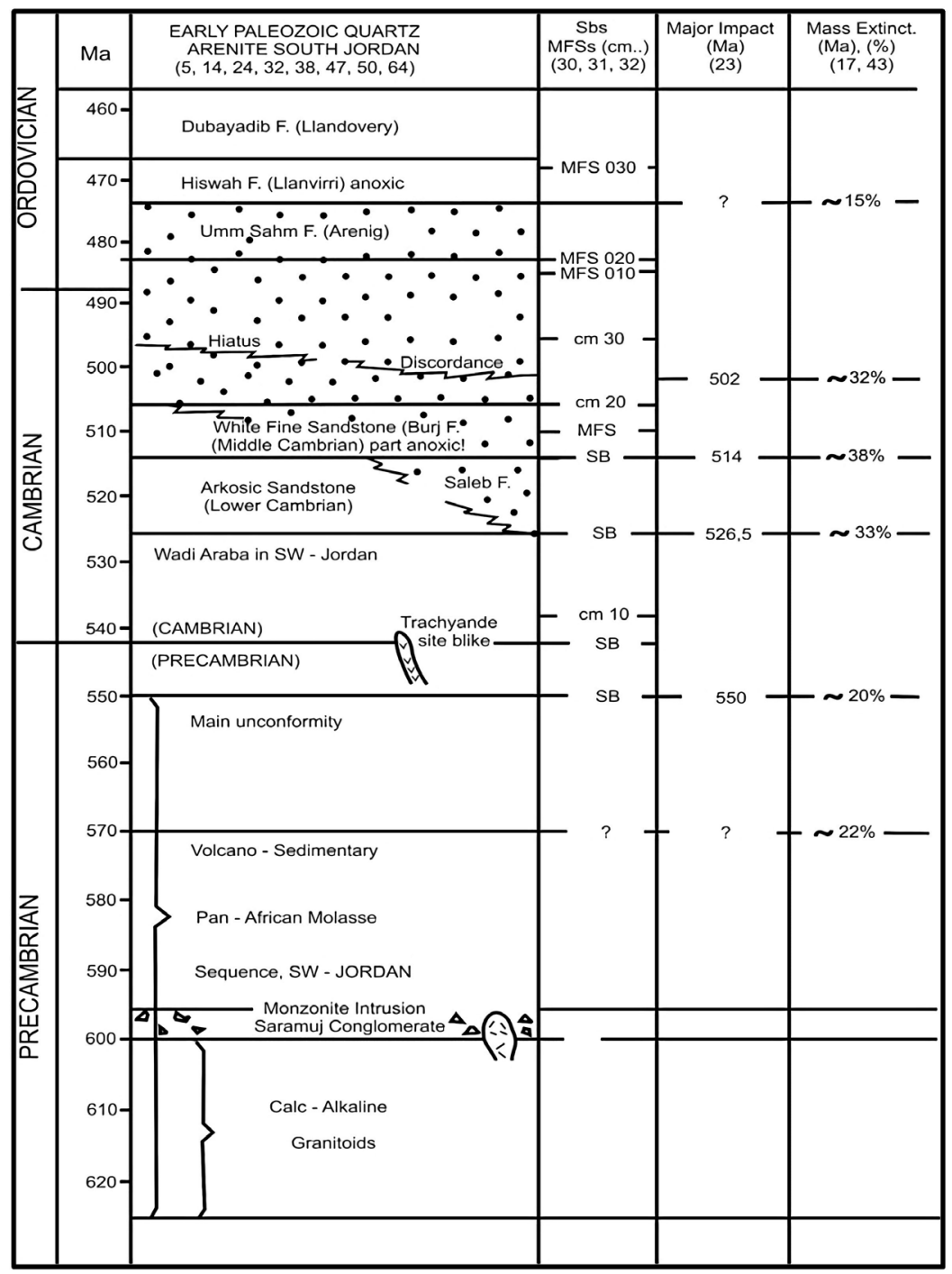

Figure 16. Synopsis of the Late Precambrian and Early Paleozoic: Correlation of quartz arenites with stratigraphy, sequence-analytical patterns (SB, MFS), major impacts' relating craters and mass extinctions. 
Table 2. Grain size parameters of early Paleozoic and early Cretaceous (Kurnub Group) Sandstone F. [47] [48] [50] in PHI units.

\begin{tabular}{ccccc}
\hline Grain size parameter/Age & $\mathrm{Md}(\mu \mathrm{m})$ & $\mathrm{M}_{\mathrm{z}}$ & $\sigma_{\mathrm{I}}$ & $\mathrm{Sk}_{\mathrm{I}}$ \\
\hline Lower Cretaceous & $120-350$ & 1.4 & $0.3-0.9$ & -0.02 to +0.6 \\
Umm Sahm F. & $180-470$ & 1.3 & $0.2-0.8$ & -0.6 to +0.4 \\
Disi F. & $260-630$ & 1.6 & $0.2-0.6$ & -0.6 to +0.8 \\
Umm Ishrin F. & $260-550$ & 1.7 & $0.2-1.1$ & -0.4 to +0.8 \\
Abu Khusheiba F. & $135-215$ & 2.2 & $0.2-1.2$ & -0.6 to +0.8 \\
Salib F. & High var. & 1.0 & $0.3-1.8$ & -0.2 to +0.1 \\
\hline
\end{tabular}

Table 3. Architectural elements (a) and Lithofacies (b) in fluvial deposits [49].

(a)

\begin{tabular}{ccc}
\hline CH & Channel & Any combination \\
\hline GB & Gravel bars and bed forms & GM. Gp. Gt \\
SB & Sandy bed forms & ST. Sp. Sh. Sl. Sr. Se. Ss \\
SG & Sediment gravity flow & Sm. Sh \\
DA & Downstream accretion macro form & St. Sp. Sh. Sl. Sr. Se. Ss \\
LA & Lateral accretion macro form & St. Sp. Sh. Sl. Se. Ss; minor Gm. Gt. Gp \\
LS & Laminated sand sheet & Sh. Sl; minor Sp. Sr \\
FF & Overbank fine sediments & Fl. Fm \\
MF & Mixed tidal flats & Sf. Sw. St. Sh. Fr. Fl \\
SF & Sandy tidal flat & St. SF. Sw. Sl. Sr \\
SW & Sand waves & St. Sp. Sh. Sl. Sr \\
TB & Tidal bar & St. Sr. Fr. Ss. Sf. Sw \\
T & Tempestite & Sh. Fl. Hcs. Scs. Sw \\
TCH & Tidal to sub-tidal channel & Sm. St. Sp. Sh \\
\hline
\end{tabular}

(b)

\begin{tabular}{ccc}
\hline Facies code & Lithofacies & Sedimentary structures \\
\hline Gmm & Matrix-supported. massive gravel & Weak grading \\
$\mathrm{Gcm}$ & Clast-supported massive gravel & Pseudo plastic debris flow \\
$\mathrm{Gt}$ & Gravel. stratified & Trough cross-beds \\
$\mathrm{Gp}$ & Gravel. stratified & Planar cross-beds \\
$\mathrm{St}$ & Sand. medium to very coarse. may be pebbly & Solitary or grouped trough cross-beds \\
$\mathrm{Sp}$ & Sand. medium to very coarse. may be pebbly & Solitary or grouped planar cross-beds \\
$\mathrm{Sr}$ & Sand, very fine to coarse & Ripple marks of all types \\
$\mathrm{Sh}$ & Sand, very fine to very coarse. may be pebbly & Horizontal lamination. parting lineation \\
$\mathrm{Sm}$ & Sand, fine to coarse & Massive or faint lamination \\
$\mathrm{Ss}$ & Sand, very fine to very coarse. may be pebbly & Broad. shallow scours \\
$\mathrm{Sl}$ & Sand, very fine to very coarse. may be pebbly & Low-angle $\left(<15^{\circ}\right)$ cross-beds \\
\hline
\end{tabular}


Continued

\begin{tabular}{ccc}
\hline Spo & Sand, fine to coarse & Overturned planar cross-beds \\
Sto & Sand, fine to coarse & Overturned trough cross \\
Sf & Fine sand with mud & Flaser-rippled stratification \\
Sw & Fine sand with mud & Wavy-rippled stratification \\
Hcs & Fine sand and mud & Hummocky cross-stratification \\
Scs & Fine sand and mud & Swaley cross-stratification \\
Fr & Sand, silt, mud & Ripple- to climbing ripple cross-lamination \\
Fm & Sand, silt, mud & Massive \\
Fl & Sand, Silt, mud & Fine lamination, very small ripples \\
\hline
\end{tabular}

Table 4. Light and heavy minerals of Sandstone F. investigated. analyzed by grain mounts in grain per cent (125 - $250 \mu \mathrm{m} ø$ ) [47]. (a) Light minerals; (b) Heavy minerals.

(a)

\begin{tabular}{ccccccc}
\hline Formation/mineral & Saleb F. & Burj F. & Um Ishrin F. & Disi F. & Um Sahm F. & Kurnub Gr. \\
\hline Quartz & $65-91$ & $72-99$ & $96-100$ & $95-100$ & $99-100$ & 100 \\
K-Feldspar & $7-29.5$ & - & - & - & - \\
Plagioclase & $0-4.5$ & $0-14.5$ & - & - & - & - \\
Muscovite & $0-3.5$ & traces & 0.4 & 0.6 & 0.3 & - \\
Biotite & 0.7 & traces & - & - & - & - \\
\hline
\end{tabular}

(b)

\begin{tabular}{ccccccc}
\hline Formation/mineral & Saleb F. & Burj F. & Um Ishrin F. & Disi F. & Um Sahm F. & Kurnub Gr. \\
\hline Zircon & $33-99$ & $2-87$ & $8-48$ & $18-48$ & $38-82$ & $12-79$ \\
Tourmaline & $0-48$ & $6-74$ & $20-81$ & $5-67$ & $3-45$ & $7-76$ \\
Rutile & $0-48$ & $3-11$ & $4-18$ & $12-43$ & $10-17$ & $1-21$ \\
Anatas \& Brookite & $0-6$ & $1-8$ & $2-24$ & $2-14$ & $0-8$ & $0-5$ \\
Epidote & $0-11$ & - & $0-11$ & $0-4$ & - & $0-5$ \\
Zoisite \& Clinozois. & 0 & $0-72$ & - & - & - & - \\
Apatite & $0-49$ & - & $0-6$ & - & - & - \\
Garnet & - & - & - & - & - & $0-4$ \\
Staurolite & - & - & - & - & - & \\
\hline
\end{tabular}

Table 5. Chemical composition of Sandstone Formations analyzed major elements (\%). trace elements (ppm). Mean values. Sample no. see Amireh [47].

\begin{tabular}{ccccccc}
\hline $\begin{array}{c}\text { Formation/Major } \\
\text { elements (\%) }\end{array}$ & $\begin{array}{c}\text { Saleb F. } \\
\text { LCR 14 }\end{array}$ & $\begin{array}{c}\text { Burj F. } \\
\text { MCKS 21 }\end{array}$ & $\begin{array}{c}\text { Umm Ishrin F. } \\
\text { CR 10 F. }\end{array}$ & $\begin{array}{c}\text { Disi F. } \\
\text { Lom } 4\end{array}$ & $\begin{array}{c}\text { Umm Sahm F. } \\
\text { Log 21 }\end{array}$ & $\begin{array}{c}\text { Kurnub Gr. } \\
\text { CRZ 27 }\end{array}$ \\
\hline $\mathrm{SiO}_{2}$ & 89.87 & 95.24 & 91.28 & 91.74 & 95.33 & 99.72 \\
$\mathrm{Al}_{2} \mathrm{O}_{3}$ & 4.43 & 2.22 & 5.07 & 5.47 & 2.98 & 0.01 \\
$\mathrm{CaO}$ & 0.09 & 0.10 & 0.76 & 0.29 & 0.12 & 0.03 \\
\hline
\end{tabular}


Continued

\begin{tabular}{|c|c|c|c|c|c|c|}
\hline $\mathrm{TiO}_{2}$ & 0.40 & 0.06 & 0.13 & 0.07 & 0.27 & 0.03 \\
\hline $\mathrm{Na}_{2}$ & 0.07 & 0.06 & 0.02 & 0.02 & 0.02 & - \\
\hline $\mathrm{K}_{2} \mathrm{O}$ & 1.51 & 0.62 & 0.02 & 0.04 & 0.04 & 0.01 \\
\hline $\mathrm{MgO}$ & 0.04 & 0.05 & 0.04 & 0.01 & 0.01 & - \\
\hline $\mathrm{Fe}_{2} \mathrm{O}_{3}$ & $0-20$ & 0.05 & 0.45 & 0.09 & 0.09 & 0.01 \\
\hline $\mathrm{MnO}$ & - & - & 0.01 & - & - & - \\
\hline $\mathrm{P}_{2} \mathrm{O}_{5}$ & 0.09 & 0.06 & 0.04 & 0.06 & 0.04 & - \\
\hline \multicolumn{7}{|c|}{ Trace elements (ppm) } \\
\hline $\mathrm{Ba}$ & 300 & 570 & 49 & 24 & 29 & 9 \\
\hline Co & 7 & - & 1 & - & 3 & - \\
\hline $\mathrm{Cu}$ & 8 & 96 & 23 & 33 & 24 & 4 \\
\hline $\mathrm{Ni}$ & 10 & 1 & 9 & 5 & 4 & - \\
\hline $\mathrm{Sr}$ & 83 & 70 & 69 & 148 & 37 & 2 \\
\hline $\mathrm{Y}$ & 12 & 4 & 6 & 4 & 2 & - \\
\hline $\mathrm{Zn}$ & 9 & 4 & 7 & 3 & 5 & 2 \\
\hline $\mathrm{Zr}$ & 131 & 52 & 49 & 27 & 127 & 7 \\
\hline B & 19 & 9 & 36 & 20 & 28 & 3 \\
\hline $\mathrm{Sc}$ & 1 & 0 & 1 & 0 & 1 & 0 \\
\hline V & 11 & 4 & 7 & 7 & 11 & 1 \\
\hline
\end{tabular}

In order to document the mineralogical contrast versus quartz arenites to be dealt, the Lower Cambrian Saleb F. will be first characterized.

\subsection{Saleb F., Lower Cambrian (526.5 - 514 Ma), 0 - 65 m}

In SW Jordan the first main unconformity terminating the volcano-sedimentary Pan-African Molasse Sequence (600 - $550 \pm 13 \mathrm{Ma}$ ) coincides with an important $\mathrm{SB}$, a major impact (crater unknown) and a mass extinction (20\%). The Precambrian b. (542 $\pm 8 \mathrm{Ma})$ meets the next SB and a trachy-andesite dike.

The overlying Saleb F. is composed of rock fragments and a mineral assemblage to be derived from local/regional source rocks like granite, granodiorite, metamorphics, all of them cropping out in SW Jordan [32] [33] [34] [35]. Proximal alluvial fans and fluvial braid plains are built up by gravel bars (GB), gravity flows (SG), diverse conglomerates $(\mathrm{Gm})$ and fanglomerates deposited on a blocked basement owning $40-70 \mathrm{~m}$ relief.

The poorly sorted clastics are medium to coarse-grained with a broad variation of grain size and varying transport energy $\left(\mathrm{M}=1.0, \sigma_{\mathrm{I}}=0.3-1.8, \mathrm{Sk}_{\mathrm{I}}=-0.2\right.$ to +1.1 in $\Phi$ units). Kaolinite/dickite dominates the clay fraction being of detrital and diagenetic origin. The subarkosic/arkosic arenites reveal a broad quantitative spectrum of light minerals (quartz: $65 \%-91 \%$, K-feldspar: $7 \%-29.5 \%$, plagioclase: $0 \%-4.5 \%$, both mica: $0 \%-10.5 \%$ ), similar like the heavy minerals: 
(zircon: $33 \%$ - 99\%, tourmaline: $0 \%$ - 48\%, rutile: $0 \%$ - 48\%, epidote: $0 \%-11 \%$, apatite: $0 \%-49 \%$ ), what should be interpreted by local rock distribution and short transport under varying transport systems.

Chemical analysis exhibits relative low $\mathrm{SiO}_{2} / \mathrm{Al}_{2} \mathrm{O}_{3}$ and $\mathrm{SiO}_{2} \mathrm{Al}_{2} \mathrm{O}_{3} / \mathrm{Na}_{2} \mathrm{O}+$ $\mathrm{K}_{2} \mathrm{O}$-ratios [47] to be explained by relatively high feldspar and kaolinite/dickite content. As trace elements $\mathrm{Ba}$ and $\mathrm{Cu}$ may indicate the influence of trachy-andesitic hydrothermalism at the end of the Precambrian era (542 Ma).

The base of the Saleb F. (526.5 Ma) represents a SB and coincides with both major impact (crater unknown) and mass extinction $(\sim 33 \%)$.

There is an indication of interplay of major impacting and plate tectonics. The same concerns the top of the Saleb F. (514 Ma) that introduces to the onset of subsidence of the Arabian Plate after peneplation (Figure 5) (see track change of both Fennoscandia and Pacific, Figure 3(A), Figure 3(B)).

\subsection{Burj/White Fine Sandstone F., Middle Cambrian (514 - $506 \mathrm{Ma}),(0$ - $40 \mathrm{~m})$}

In SW Jordan the Middle Cambrian Burj F. indicates a significant sea level rise (MFS: $506 \mathrm{Ma}$ ) above the SB of the Pre-Sic Angudan Unconformity (514 Ma), (Figure 5), which is well documented by trilobites, brachiopods, and Cruziana Ichnofacies (C. aegyptica, salomonis, nabateica), [36] [37] [50] (Figure 8, Figure 9).

The general paleogeographic patterns make obvious the interfingering of shallow marine carbonates and black shales of subtidal to mixed intertidal flats and lagoons towards the Tethys Sea way (Zerqa Ma'in: [47] [50] with siliciclastic fluvial and tidal braid plains built up by tidal bars (TB), flat fluvial channels $(\mathrm{CH})$, laminated sand sheets (LS), and sandy bed forms (SB) deposited towards the Arabian/Nubian hinterland (Abu Khusheiba, Quweira), [32] [36] [37].

While the lower/middle part of this sequence exhibits subarkosic/arkosic sandstones, the upper part intraformationally developed to quartz arenite facies [47]. This is of interest since the middle part of the Burj F. owns volcanic breccias, isolated angular quartz porphory clasts in silty sandy matrix (tuff?) or in fine-grained sandstone indicating an eruptive event accompanied by hydrothermal baryte cementation, abundance of zoisite/clinozoisite, and Cu-mineralization at Feinan, Wadi Araba [51] [52].

The fine to median-grained quartz arenites $\left(\mathrm{Md}=135-215 \mu \mathrm{m}^{\Phi}\right)$ have variable sorting $\left(\sigma_{\mathrm{I}}=0.2-1.2\right)$ and a negative to positive skewness $\left(\mathrm{Sk}_{\mathrm{I}}=-0.6\right.$ to $+0.8)$.

High quantitative variation concerns both light minerals (quartz: 72\% - 99\%, feldspar: $(0 \%-14.5 \%)$ and heavy minerals (zircon: $2.0 \%-87.0 \%$, tourmaline: $6.0 \%-74 \%$, rutile: $3.0 \%-4.0 \%$ and exceptionally zoisite/clinozoisite: $0 \%-72 \%$; disappearance of unstable heavies contrasts to the Saleb F.

The increase of the $\mathrm{SiO}_{2} / \mathrm{Al}_{2} \mathrm{O}_{3}$ and the $\mathrm{SiO}_{2}+\mathrm{Al}_{2} \mathrm{O}_{3} / \mathrm{Na}_{2} \mathrm{O}+\mathrm{K}_{2} \mathrm{O}$ ratios relates to kaolinite/dickite, feldspar decrease, and quartz syntaxial overgrowth [14]. 
The significant facies change from subarkosic/arkosic arenite to quartz arenite in the upper part of the section follows a major impact (514 Ma) with unknown crater, however, with a mass extinction around the same time (38\%).

The cause of regional transgression correlates with a global sea level rise possibly at the end of the late Precambrian glacial period [30] [31] [32], when transgressive black shales provided a MFS in SW Jordan (Wadi Numeiri) and across the whole Arabian Plate (506 Ma).

The transgression started from the Baltic Side of the Tethys across Turkey and covered extended areas of the Near East [31].

\subsection{Umm Ishrin F., Middle/Late Cambrian (506 - 500.5/496? Ma), $110 \mathrm{~m}$}

By HST-level, sand flats (SF) of unconfined braided rivers prograded northwestward onto the Arabian Platform in South Jordan. Thus, sandy bed forms $(\mathrm{SB})$, downstream accretion (DA), and flat channels $(\mathrm{CH})$ are the main architectural elements (Figure 8, Figure 9) [32] [36] [37].

From time to time, short Tethys incursions left Cruziana-bearing pelite layers intercalating the quartz arenites. All in all, the whole sequence appears relatively monotonous and by moderate transport energy dominated.

The quartz arenites are median to coarse-grained ( $\mathrm{Md}: 260-550 \mu \mathrm{m})$, poorly sorted $\left(\sigma_{\mathrm{I}}: 0.2-1.1\right)$, and with varying skewness $\left(\mathrm{SK}_{\mathrm{I}}:-0.4\right.$ to +0.8$)$. Light minerals are almost completely restricted to quartz (96\% - 100\%) with syntaxial overgrowth. Dickite dominates as cement neoformation. Heavy minerals show a similar qualitative composition and quantitative variation like the underlying Whitish Weathered Sandstone of the Burj F.: zircon (8\% - 48\%), tourmaline $(20 \%-81 \%$, rutile $(4 \%-18 \%)$, anatase and brookite $(2 \%-24 \%)$, in addition: epidote (O-11\%), apatite $(0 \%-6 \%)$, without zoisite/clinozoisite.

The chemical composition of major elements $\left(\mathrm{SiO}_{2}: 91.28 \%, \mathrm{Al}_{2} \mathrm{O}_{3}: 5.07 \%\right)$ relates to the high dickite content which in turn relates to higher $\mathrm{SiO}_{2}+$ $\mathrm{Al}_{2} \mathrm{O}_{3} / \mathrm{NaO}_{2}+\mathrm{K}_{2} \mathrm{O}$-ratios, similar like the underlying $\mathrm{F}$. Increased $\mathrm{Sr}$ and $\mathrm{B}$ contents are of marine influence.

There appears a significant coincidence of a SB amidst the Umm Ishrin F. $(502 \mathrm{Ma})$ related to both tracks of Fennoscandia and Hawaii as well as with a mass extinction (32\%). Being aware of analytical error, this event might meet the Middle/Upper Cambrian b. (501 Ma). Much discussed is the top of this F. and its contact to the overlying Disi F. where an abrupt change of architectural elements (OF, LS, DA) and transport energy becomes obvious.

\subsection{Disi F.: Upper Cambrian/Lower Ordovician, (500.5/496 - $483 \mathrm{Ma}) 250 \mathrm{~m}$}

The basal transition zone (hiatus, discordance, open time-span) represents a "fact under question" (Figure 10(A), Figure 10(B)): an abrupt color change (red-brown $\rightarrow$ white), increasing thick bedding, high sedimentary load, and transport energy, scattered quartz pebbles (up to $12 \mathrm{~cm}^{\Phi}$ ) and gravel lags, critical 
transport velocity $\rightarrow$ massive overturned cross bedding, sliding, and mass flows are typical features. These sedimentologic patterns demand cyclic atmospheric hazards combined with heavy "sturz rain" [15] [16] [18].

This transition zone comprises both an important MFS (496 Ma $=\mathrm{Cm} 30$ ) across the Arabian Plate and Price's major impact (502 Ma) coinciding with a SB and with a mass extinction (32\%) at the same time.

The almost friable sequence is built up of 10 - 12 fining upward cycles owning lag deposits (Figure 11). Main architectural element in distal braid plains is northwestward downstream accretion sand waves (DA). Occasionally, Cruziana-bearing pelite intercalations indicate marine incursions. The upper part of the Disi F. reveals a lower Ordovician age by Cruziana furcifera, C. goldfussi, and C. rugosa [38] [39] [40].

The granulometric data are similar to those of the Umm Ishrin F. (Md: 260 $630 \mu \mathrm{m}) \sigma_{\mathrm{I}}: 0.2-0.6, \mathrm{Sk}_{\mathrm{I}}:-0.6$ to +0.8$)$.

The Disi F. owns $95 \%$ - 100\% quartz. Syntaxial overgrowth started with randomly scattered authigenic patches on the surface of detrital grains. The pore space $(\sim 24 \%)$ is filled with dickite recrystallized from primary kaolinite as subject of burial depth and geothermal gradient.

Comparable with the Umm Ishrin F., the heavy mineral assemblage shows also a high quantitative variability consisting on: zircon $18 \%-48 \%$, tourmaline $5 \%$ - $67 \%$, rutile $12 \%$ - $43 \%$, anatase and brookite $2 \%$ - $14 \%$, epidote $0 \%-4 \%$. As Figure 1(A) shows, even ultra-stable heavies underlie strong etching and dissolution. So the originally broad mineral spectrum of magmatic/metamorphic rocks of source areas underwent selective reduction.

The Disi F. exhibits the lowest $\mathrm{SiO}_{2} / \mathrm{AL}_{2} \mathrm{O}_{3}$ ratio and a high $\mathrm{SiO}_{2}+\mathrm{Al}_{2}$ $\mathrm{O}_{3} / \mathrm{Na}_{2} \mathrm{O}+\mathrm{K}_{2} \mathrm{O}$ ratio depending on quartz and dickite contents. Increased $\mathrm{Sr}$ concentrations indicate higher marine influence.

The top of this F. coincides with a plate-wide MFS (020), with the end of high detrital input and with the beginning of South Hemisphere glaciation.

\subsection{Umm Sahm F.; Arenig (483 - 474 Ma), 250 m}

While the base of this F. meets the MFS (020), its top coincides approximately with the Llanvirn base, with a SB, and with the increase of feldspar and dickite ( $\sim 47 \mathrm{Ma}$ ). A braid plain delta persists throughout the sequence during gradual sea level rise, developing from DA, SB, TB elements to sand and mixed tidal flats and channels (LS, FF, CH), ending in the upper part in fining upward sequences of lower detrital input (Figure 11).

The quartz arenite is medium-grained and moderately to well sorted ( $\mathrm{Md}=$ $180-470 \mu \mathrm{m}^{\Phi}, \sigma_{\mathrm{I}}=0.2-0.8, \mathrm{Sk}_{\mathrm{I}}=-0.6$ to +0.4$)$.

This F. represents the purest quartz arenite in Jordan (quartz: 99\% - 100\%), distinct syntaxial overgrowth (well consolidated), with traces of muscovite. The heavy mineral assemblage underlines the extremely high maturity: zircon, tourmaline, rutile, anatase and brookite similar to that of the Disi F. by the same 
high quantitative mineral variation, too, without any "unstables". Through the Umm Ishrin F. and the Disi F., kaolinite $\rightarrow$ dickite is the dominant clay mineral neoformation working as cement.

Accordingly, $\mathrm{SiO}_{2} / \mathrm{Al}_{2} \mathrm{O}_{3}$ and $\mathrm{SiO}_{2}+\mathrm{Al}_{2} \mathrm{O}_{3} / \mathrm{Na}_{2} \mathrm{O}+\mathrm{K}_{2} \mathrm{O}$ ratios are directed by quartz and dickite. Sr and B-contents are similar like in the Disi F. since both elements are lacking substitution in the lattice of both minerals.

The extremely high maturity relates to manifold reworking, re-transport and re-sedimentation (including Disi-material!) in different fast changing environments to generate almost 100\% "glass sand".

The Umm Sahm/Hiswah F. b. relates to increasing sea level rise introducing anoxic conditions on ocean floor, defined by MFS 030 (469 Ma). Surprisingly not indicated in Price's major impact sequence are two main mass extinctions around $\sim 474 \mathrm{Ma}$, both of lower species loss ( 15\%).

The next major impact event occurred around the Dubaydib/Mudawwara F. (Caradoc: 455.4 - $456.0 \mathrm{Ma}$ ).

Now we jump from the Early Paleozoic into the Early Cretaceous:

\subsection{Kurnub Group, Early Cretaceous (145.5 - 99.6 Ma), 220 m, (Plate 3 B, G)}

The eastern Mediterranean, the Hellenides, and the Near/Middle East underwent mountain-building processes through the time-span Tithonian to Hauterivian comprising magmatism in Lebanon and Palestine [41] [42]. The Inner Hellenic ophiolite-decorated suture developed in Greece by the obduction of the Guevgnelige/Paikon nappe onto the Almopias-Unit [53] [54].

The siliciclastic Kurnub Group of Jordan that crops out in South Jordan and along the Jordan Rift shoulder up to the Zerqa River area in the north, commences by a $\sim 1.5 \mathrm{~m}$ thick paleosol (i.e. King Talal Dam) revealing a complex clayey/clastic sequence comprising the interval Berriasian to lower Hauterivian [41]. It corresponds to the SB wide-spread across the Arabian Plate [30] [31].

Under a moderate warm humid climate the siliciclastic deposition began during Hauterivian when the general paleogeographic setting was similar to that of the early Paleozoic: the Arabian/Nubian shield as source area, the Arabian Platform as depositional environment for siliciclastic input that prograded northwestward towards the Tethys Seaway [1]. Thus, it is not surprising that in former days both Disi F. and Kurnub Gr. were occasionally confused in SW-Jordan when directly overlying [55].

Figure 14 shows the interfingering of three main Tethys incursions with the quartz arenite that dominates the entire southern area. The coastal swamps (incl. lignites) and interbedded shelf carbonates accompanied by mixed siliciclastic/carbonate sequences, coincide with global sea level fluctuations [56] [57], while the central and southern areas of the Jordanian Platform exhibit braid plains with fining upward cycles (basal conglomerates) of quartz arenites throughout the complete Kurnub Gr. absolutely comparable with the early Pa- 
leozoic quartz arenites owning the same architectural elements $(\mathrm{CH}, \mathrm{GB}, \mathrm{SB}$, DA, FF) [41] [47].

The petrologic composition of the source areas (magmatites, metamorphics) was more or less similar as during the early Paleozoic, except the additional occurrence of staurolite-bearing amphibolite facies [5] [42].

All in all, the granulometric data of the median to coarse-grained relatively well-sorted quartz arenites are comparable with those of the early Paleozoic sequences (Md: $1.2-2.3, \mathrm{Mz}: 1.39-2.36, \sigma_{\mathrm{I}}=0.31-0.90, \mathrm{Sk}_{\mathrm{I}}-0.02$ to +0.56 ).

As light mineral, quartz (97\% - 100\%) provides, besides the Umm Sahm F., the purest quartz arenites on the platform. Undulose monocrystalline and polycrystalline grains show slight syntaxial overgrowth, with a broad spectrum of roundness. As clay mineral, kaolinite (without dickite) shows poor to moderate crystallinity.

The heavy mineral assemblage is comparable with that of the early Paleozoic F., however with staurolite $(0-4)$ indicating an additional part-source area: zircon $12 \%-78.7 \%$, tourmaline $6.6 \%-76 \%$, rutile $1 \%-21.1 \%$, anatase and brookite $0 \%-5.1 \%$. Unstable heavies (garnet, hornblende, zoisite, epidote, and apatite) are rarely found in marine sediments because of better conservation by cements and higher $\mathrm{pH}$, and rather towards the southern source areas. Carbonates and clay matrix are favorable for preserving the "unstables" at all.

Figure 17 documents the relatively short time-span of temporal coincidence of paleosol formation in Jordan (145.5 - $133 \mathrm{Ma}$ ), magmatism in Anti-Lebanon and Inner Hellenic mountain building (145.5 Ma) after a SB that developed across the Arabian Plate during Late Tithonian (149.5 Ma). The next SB falls into the interval of paleosol formation in Jordan.

\section{Discussion and Conclusions (Plate3)}

Research work carried out until now across Jordan evidence the unique character of its geologic setting as part of the Arabian Platform. The focus is directed on the similar paleogeographic framework provided throughout hundred millions of years comprising the according similar sequence-analytical patterns by cyclicity, predominantly through the early Paleozoic and lower Cretaceous.

Based on tectonic quietness and global sea level undulation, the northwestern edge of the Arabian Plate has developed a surprisingly high "sensitivity" during the interplay of marine incursions from the Tethys Seaway and the progradation of clastic braid plains/deltas fed by the Arabian/Nubian Shield what is manifold realized by even thin pelite layers partially bearing Cruziana-Ichnofacies, in most cases relating to global sea level rise [39] [40] [56] [57].

Haq's and Al-Qahtani's Chart of the Arabian Plate submits an excellent basis for manifold geoscientific correlations like formation boundaries with sequence-analytical patterns (SB, MFS), major impacts (rare events), mass extinctions, and even mineralogic/petrographic variations.

The Chart is also useful for representing the contradiction between "classic 


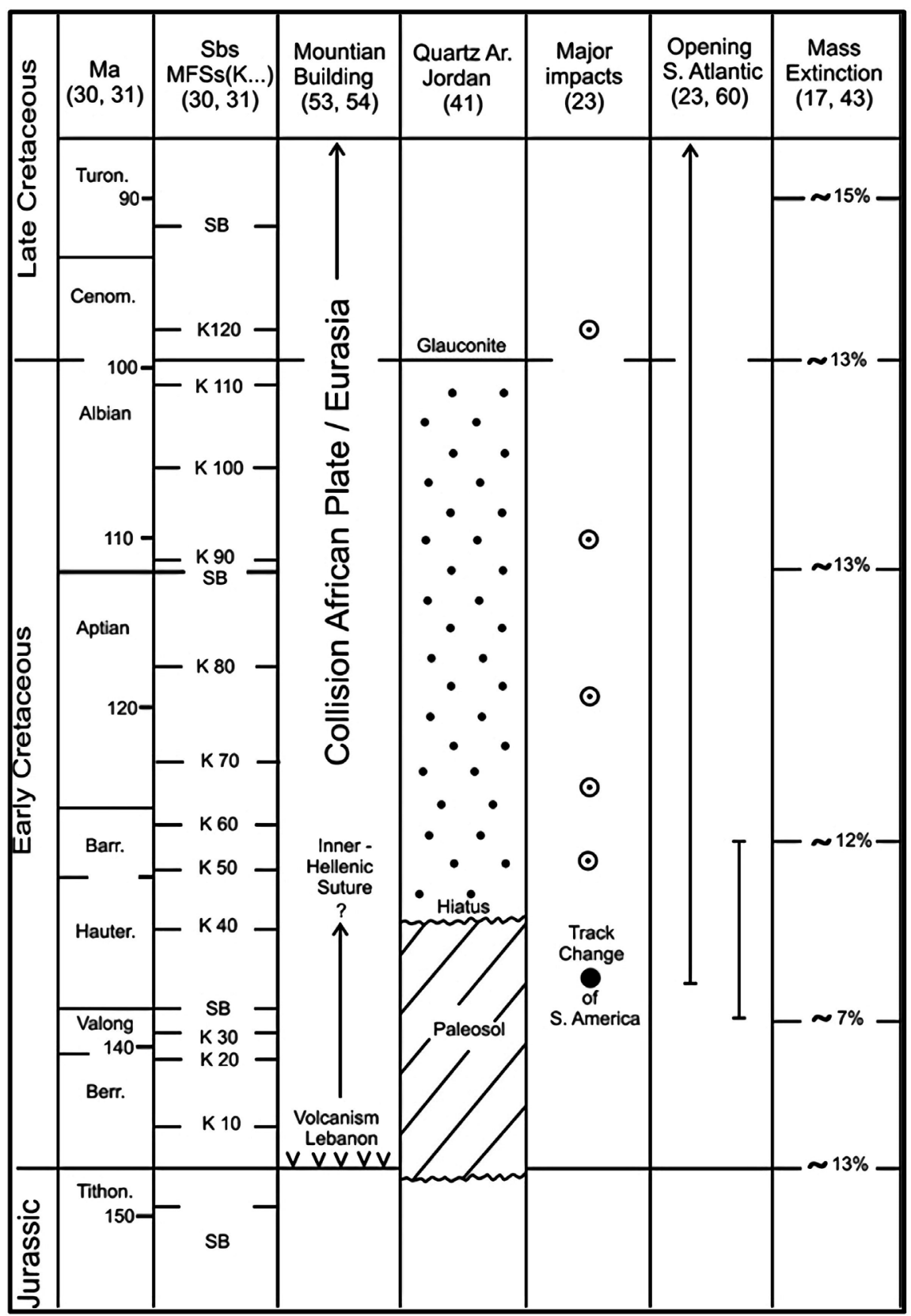

Figure 17. Synopsis for the Early Cretaceous (145.5 - 99.6 Ma) representing the correlation of SBs and MFSs, mountain building (Greece, Near East), paleosol formation, hot spot activity, Paraña/Etendeka Flood Basalts, track change of South America, "rare events" and mass extinctions [17] [23] [30] [31] [43] [53] [54] [60].

diagenesis" (including intrastratal solution and hydrothermalism by increasing burial depth) and the new aspect of qualitative/quantitative reduction of the primary mineral content of source rocks by a dramatic change of "atmospheric chemistry" after a major impact [15] [16] and plume volcanism [23] [28] what finally results in quartz arenite deposits of very high maturity.

Dissolution processes under such conditions also concern ultrastable heavy minerals like tourmaline and zircon as well as common quartz all attacked by 
mixtures of aggressive acids $\left(\mathrm{HNO}_{3}, \mathrm{H}_{2} \mathrm{SO}_{4}, \mathrm{HF}, \mathrm{HCl}\right.$ and $\left.\mathrm{H}_{2} \mathrm{CO}_{3}\right)$.

For contrasting the spectrum of the primary mineral content versus the final diagenetic stage, Figure 18 shows three thin sections drawn from an arkosic/ subarkosic arenite of the fluvial Saleb F. (A), a fluvial braid-plain quartz arenite of the Disi F. (B), and a subarkosic arenite of marine Silurian (C).

Generally spoken, syntaxial overgrowth of quartz is relatively low in contrast to massive dickite neoformation where the latter replaces quartz with increasing burial depth.

Quartz arenites without any marine influence lack in most cases all unstable
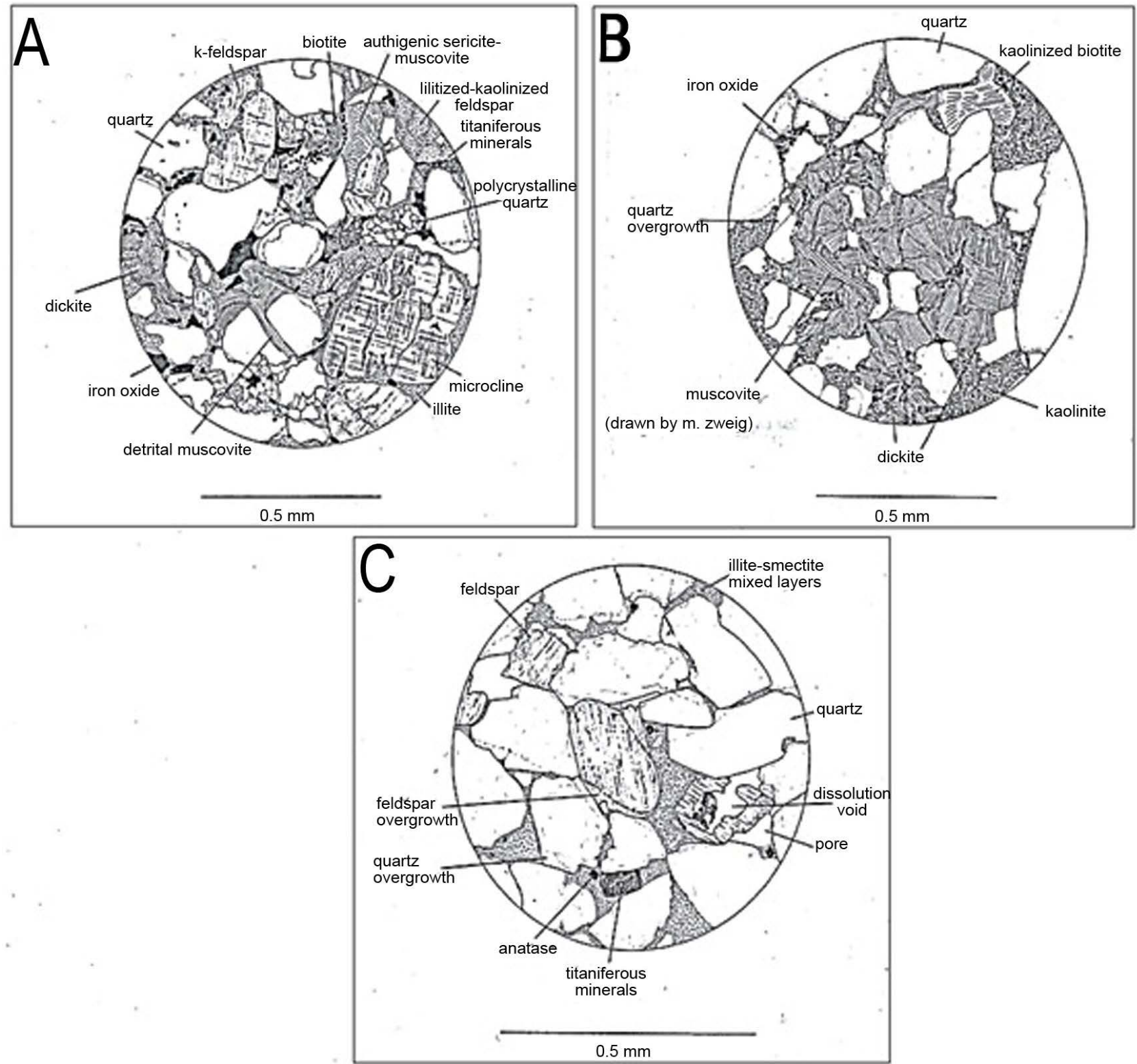

Figure 18. Diagenetic patterns in Early Paleozoic Sandstones of SW-Jordan (drawn from thin sections by Maren Zweig, Dipl. Geologist, formerly Braunschweig Techn. University) 1986/87 [14] [47]. (A) Basal Conglomerate-Bedded Arkosic Sandstone (Lower Cambrian). (B) Quartz arenite, Umm Ishrin F. (Middle/Upper Cambrian). Neoformation of dickite that replaces quartz. (C) Conularia-Nautoloidea Sandstone F. (Silurian). Marine environment prevents feldspar dissolution ( $\mathrm{pH} \sim 8$ ). 
"heavies" (apatite' garnet, hornblende, epidote, zoisite) in contrast to the arkosic Saleb F. and marine clastics (Silurian, marine intercalations in fluvial quartz arenites relating to $\mathrm{pH}>7$ resp. primary clay mineral conservation).

The burial history of the Phanerozoic suite of Jordan is shown in Figure 19 after Lopatin's Time-Temperature-Index of Maturity TTI $=\sum_{n_{\min }}^{n_{\max }}(\Delta T n)\left(r^{n}\right)$, [58]. It sets the field of dickite neoformation in SE Jordan (Mudawwara) below $\sim 2000 \mathrm{~m}$ at a temperature of $\sim 85^{\circ} \mathrm{C}-90^{\circ} \mathrm{C}$ [14]. The Saleb F. reached the onset of hydrocarbon generation (liquid window) during the early Cretaceous.

The surprisingly high quantitative variation of "ultrastable heavies" relates to manifold changing $\mathrm{pH}$, reworking, -transport, and resedimentation throughout a high complexity of architectural elements and lithofacies types under variable transport energy and "acidic sturz rain" conditions.

Roundness of quartz pebbles and grains covers a broad spectrum from very well rounded scattered pebbles in the Disi F., poorly rounded or even angular despite long transport distance and frequent intra-formational reworking. We relate these phenomena to the high acidity of both transport medium and pore water as well as to the diagenetic replacement by kaolinite/dickite neoformation.

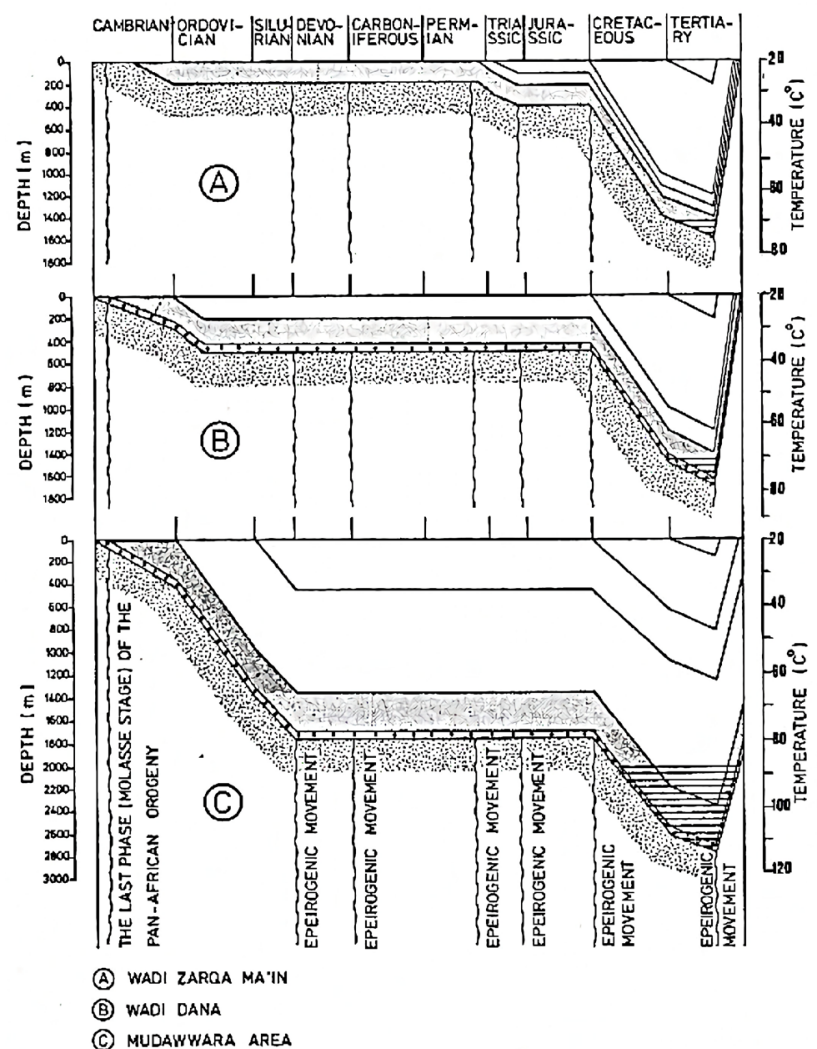

\begin{tabular}{lllll} 
D1 & & & \\
\hline $\begin{array}{l}\text { Temperature } \\
\text { Interval }\left({ }^{\circ} \mathrm{C}\right)\end{array}$ & $r^{n}$ & $\Delta \mathrm{T}(\mathrm{Ma})$ & $\Delta \mathrm{TTI}$ & $\mathrm{TTI}_{\text {wotal }}$ \\
\hline $20-30$ & $2^{.8}$ & 34 & 0.13 & 0.13 \\
$30-40$ & $2^{.7}$ & 31 & 0.24 & 0.37 \\
$40-50$ & $2^{\cdot 6}$ & 21 & 0.33 & 0.70 \\
$50-60$ & $2^{-5}$ & 20 & 0.63 & 1.33 \\
$60-70$ & $2^{-4}$ & 21 & 1.31 & 2.64 \\
$70-80$ & $2^{-3}$ & 25 & 3.13 & 5.77 \\
$80-90$ & $2^{-2}$ & 305 & 76.25 & 82.02 \\
$90-100$ & $2^{-1}$ & 31 & 15.5 & 97.52 \\
$100-110$ & 1 & 48 & 48.00 & 145.52 \\
\hline
\end{tabular}

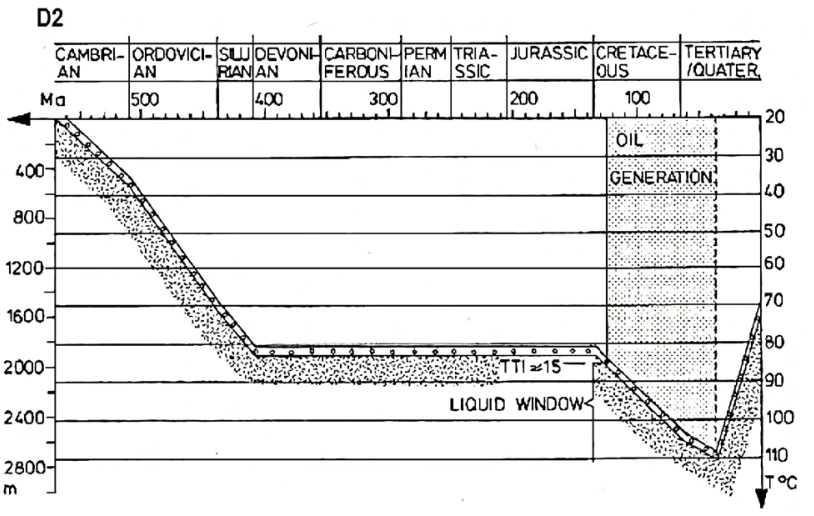

Figure 19. Burial history of the Paleozoic-Cretaceous Sandstone F. at Wadi Zerqa Ma'in (A), Wadi Dana (B) and Mudawwara area/SE-Jordan (C). The lined field represents the occurrence of dickite neoformation [14]. D1: Lopatin's [58] time/temperature index TTI applied to the base of the Saleb F.; $r=2$ (temperature factor), $\mathrm{n}$ temperature index value, $\mathrm{T}$ time span. $\mathrm{TTI}=\sum_{n_{\min }}^{n_{\max }}(\Delta T n)\left(r^{n}\right) ; \mathrm{D} 2$ : Burial history of the Saleb F. indicating the onset of hydrocarbon generation (liquid window) during the Early Cretaceous based upon Lopatin's method. 
It cannot be excluded that the fining-upward-cycles of the Disi F. and Lower Cretaceous Kurnub Gr. may indicate a cyclicity of changing atmospheric chemistry as cause of "rare events".

Haq's and Al-Qahtani's chronostratigraphic charts (Early Paleozoic, Jurassic/Cretaceous) open our horizon, in connection with Price's Major Impacts, and Rampino's Mass Extinctions for a challenging field of highly possible correlations as follows:

Correlations throughout the Early Paleozoic (Figure 16):

Most of the lithostratigraphic boundaries of the Jordanian Platform coincide with the chronostratigraphic boundaries on the Arabian Plate.

The end of magmatism of the Pan-African Molasse-Sequence and a SB meet the Precambrian/Cambrian b. (542 Ma).

Most of the SBs and Major Impacts correlate with the lithostratigraphic resp. with the chronostratigraphic b. (542, 526.5, 514, 506, 502, 456/455.4 Ma).

Mass Extinctions meet Major Impacts on $550 \mathrm{Ma}(\sim 20 \%), 526.5 \mathrm{Ma}(\sim 33 \%)$, $514 \mathrm{Ma}(\sim 38 \%), 502 \mathrm{Ma}(\sim 32 \%)$ and an anoxic event $469 \mathrm{Ma}=\mathrm{MFS}(474 \mathrm{Ma}$ $\sim 15 \%)$.

Anoxic pelites (Burj F., Hiswah F.) correlate with worldwide sea level rise: MFS $506 \mathrm{Ma}=\mathrm{Cm} 20,469 \mathrm{Ma}=\mathrm{Cm}$ 30, $454 \mathrm{Ma}=\mathrm{Cm} 040$.

MFS coincide on both Jordanian Platform and the Arabian Plate.

Correlations throughout the Early Cretaceous (Kurnub Group) (Figure 17):

There appears a temporal relation between geologic/sedimentologic processes that happened in the Eastern Mediterranean and the Paraña-Event [23] in the South Atlantic (140 - $135 \mathrm{Ma})$. The latter relates to the initial outbreak of the hot spot Tristan da Cunha what obviously introduced the opening of the South Atlantic [28]. This magmatic event caused the effusion of both Paraña and Etendeka flood Basalts [23] [28].

Thus, magmatism in the Levant (i.e. Anti-Lebanon) coincides with the Jurassic/Cretaceous b. (145.5 Ma) while a hiatus (paleosols in Jordan and adjacent areas) as well as the development of the Inner Hellenic suture (ophiolites) in Greece cover the time-span 145.5 - $130 \mathrm{Ma}$ comprising a SB (136.4 Ma) on the Arabian Plate.

A track point of South America was set by Price at $138 \mathrm{Ma}$ (Figure 20): the first significant track change occurred on 135.1 Ma which would fix the "rare event" (birth of the hot spot), immediately followed by the effusion of both Flood Basalts above cited. Radiometric age analysis $\left({ }^{40} \mathrm{AR} /{ }^{39} \mathrm{Ar}\right)$ cover a time-span of the lava flows of $137-127 \mathrm{Ma}$ [59]. Obviously, the hot spot remained long-lasting on the Mid-Atlantic Ridge (MAR), since recently it belongs, some $400 \mathrm{~km}$ east of it, to the African Plate (Figure 20). Both plates followed a northern drift component during MAR-Spreading (Figure 20): South America towards NW, South Africa towards N.

Because of temporal coincidence of the hot spot magmatism (Paraña, Etende- 
ka), plates' motion, and the geologic processes in the Near East, there is reason to accept a very high probability to find the cause for these processes in the compressive role of the northward moving African plate towards the Arabian and Eurasian Plate during the interval 145.5 - 130 Ma (Figure 20).
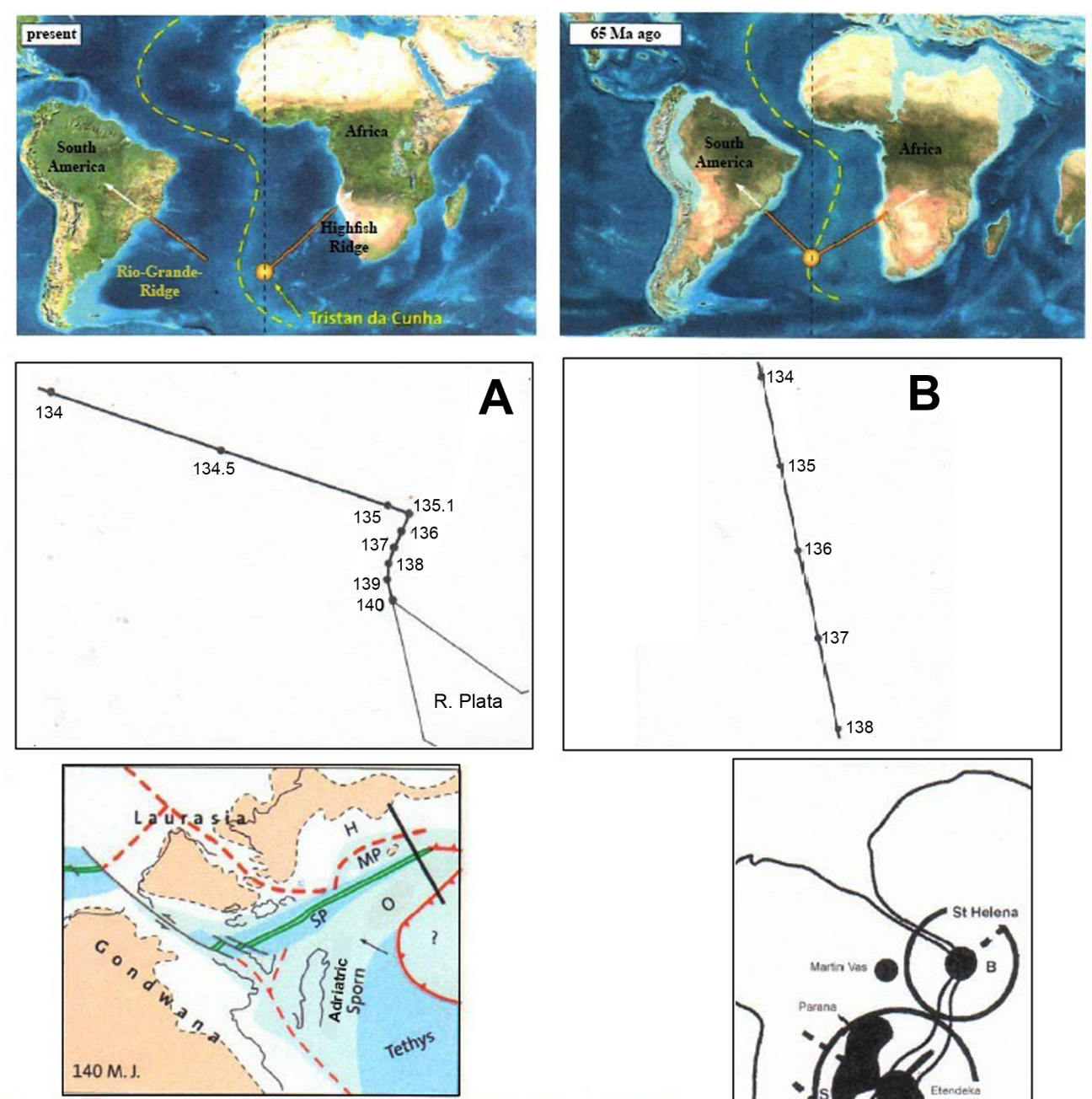

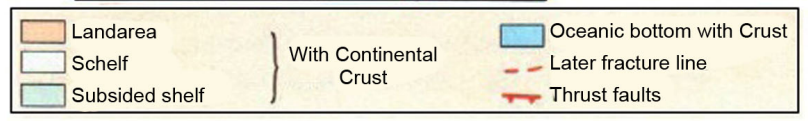

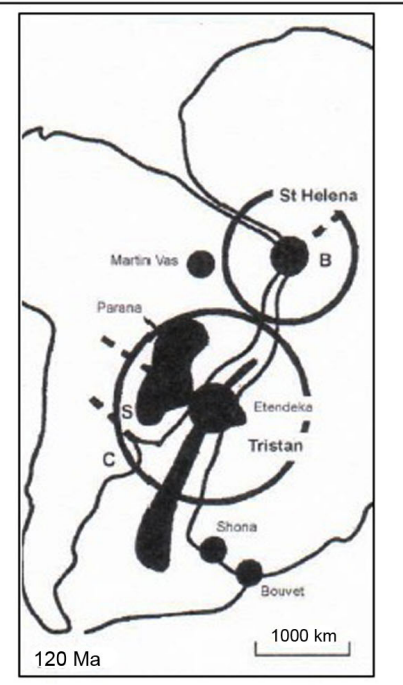

Figure 20. Beginning of the opening of the South Atlantic [23] [28] [59] [60]. Below: Several hot spots (mainly Tristan da Cunha) became active on Gondwana after $140 \mathrm{Ma}$ initiating the separation of Gondwana into South America and Africa, combined with the effusion of both Paraña and Etendeka Flood Basalts. (A) Abrupt change of track direction at 135.1 Ma that would indicate a gigantic major impact event after Price [23] relevant for global precipitation of hot acidic "sturz rain". So South America then moved northwestward while the eastern part (Africa) continued straight its motion northward (B). The central figure [28] represents the collision of the African Plate with Laurasia probably comprising mountain building in the Hellenides (Inner Hellenic Suture) and a wide-spread hiatus (paleosols) across the Near East through 140 - $130 \mathrm{Ma}$. Above: Continuous opening of the Atlantic $65 \mathrm{Ma}$ ago and nowadays. Note Tristan da Cunha remained on the African Plate. 
Global mass extinctions took place around the Jurassic/Cretaceous b. (145.5 Ma: 13\%, 138/137 Ma: 7\%) = onset of Paraña magmatism followed by a SB $(136.4 \mathrm{Ma})=$ Valanginian/Hauterivian b., another "rare event" (128 Ma: 12\% and 113 Ma: 13\%) coinciding with a SB = Aptian/Albian b., and finally on 90 Ma: $45 \%$ = Albian/Cenomanian b. accompanying the geologic processes (Figure 17).

While MORB-Basalts are classic tholeiites, hot spot basalts are indeed also tholeiites, however associated with alkali basalts that own higher concentrations of lithophile elements like K, Rb, P, Ti, and Light Rare-Earth-Elements [28]. Both Paraña and Etendeka Flood Basalts belong to the latter. Thus, Frisch explains the chemical difference by slower magmatic activity (magma differentiation), Price postulates a major impact what caused that the Paraña Flood Basalts contain material originating from molten continental lithosphere? Presuming that this was the most energetic "Rare Event" throughout the Phanerozoic and assuming a crater diameter of $>500 \mathrm{~km}[23]$.

Thus, after Price, there is no other known geological process that could have caused such an abrupt direction change of plate motion which would not be imaginable by a plume.

He infers, in connection with Wilson [60], that a plume head of $\sim 2000 \mathrm{~km}^{\Phi}$ with a maximum elevation of $\sim 2 \mathrm{~km}$, cannot generate the magnitude of lateral stress required to split a super-continent what demands a more powerful mechanism. So, according to Price, Gondwana was struck by a large extraterrestrial body about 135.1 Ma ago that gave rise for both Paraña and Etendeka Flood Basalts.

Flood Basalt effusions commonly produce many 100,000 to millions $\mathrm{km}^{3}$ within less than one to a few million years spreading out over many 100,000 $\mathrm{km}^{2}$, even several $\mathrm{km}^{3}$ basalt/year. The outflow occurs in cycles predominantly on ocean floor [28].

The dualistic scenario Major Impact/Hot Spot (Plume, Super Plume) provokes the question whether the tremendous output of basaltic lava and magmatic gases of plumes may induce a similar change of atmospheric chemistry like major impacts do in order to get a similar chemical influence on mineral solubility of surface clastics. Table 6 and Table 7 list up the composition of volcanic gases and magmatic gases during outbreaks on Kilauea/Hawaii and Erta-'Ale/Ethiopia [9].

If the effects of such volcanic gas mixtures and their relating acids produced by hot spots, would be comparable with those of major impacts, then the extremely high compositional maturity and the angular-corroded form of clastic quartz grains of the Lower Cretaceous Kurnub quartz arenites deposited on the Jordanian Platform would be explained herewith. Thus, the "diagenetic/atmospheric processes" would be comparable with those of the Early Paleozoic quartz arenites.

The Early Cretaceous period exhibits throughout $\sim 45$ Ma 12 MFSs and $~ 12$ 
Table 6. Analyses of fumarole gases from Kilauea, Hawaii and Erta'Ale, Ethiopia, both basaltic sources (mol\%) [9].

\begin{tabular}{ccccccc}
\hline \multicolumn{2}{c}{ Kilauea/Hawai } & \multicolumn{5}{c}{ Erta'Ale/Ethiopia } \\
\hline Sample & $\mathrm{J} 18$ & $\mathrm{~J} 11$ & $\mathrm{~J} 13$ & Rep. Samp. & Rep. Samp. & Av. 18 Samp. \\
$\mathrm{H}_{2} \mathrm{O}$ & 36.18 & 61.56 & 67.52 & 84.8 & 69.9 & 79.4 \\
\hline $\mathrm{CO}_{2}$ & 47.68 & 20.93 & 16.96 & 7.0 & 15.8 & 10.4 \\
$\mathrm{CO}$ & 1.46 & 0.59 & 0.58 & 0.27 & 0.68 & 0.46 \\
$\mathrm{COS}$ & & & & 0.001 & 0.01 & 0.009 \\
$\mathrm{SO}_{2}$ & 11.15 & 11.42 & 7.91 & 5.1 & 10.2 & 6.5 \\
$\mathrm{SO}_{3}$ & 0.42 & 0.55 & 2.46 & & & \\
$\mathrm{~S}_{2}$ & 0.04 & 0.25 & 0.09 & $0.41^{\dagger}$ & 0.0 & $0.5+$ \\
$\mathrm{HCl}$ & 0.08 & 0.00 & 0.20 & 1.28 & 1.22 & 0.42 \\
$\mathrm{H}_{2}$ & 0.48 & 0.32 & 0.96 & 0.85 & 2.11 & 1.49 \\
$\mathrm{~N}_{2}$ & 2.41 & 4.13 & 3.35 & 0.10 & 0.25 & 0.18 \\
$\mathrm{Ar}$ & 0.14 & 0.31 & 0.66 & 0.001 & 0.001 & 0.001 \\
\hline
\end{tabular}

Sources: Shepherd. 1938. p. 321 (Kilauea); Giggenbach and Le Guern. 1976. p. 26 (Erta'Ale). The three Kilauea samples are Shepherd's Nos. J8. J11. J13; the first two from Erta'Ale are representative individual samples and the third is an average of 18 samples. Shepherd calculated all chlorine as $\mathrm{Cl}_{2}$; his numbers are expressed here as $\mathrm{HCl}$, for ease of comparison with the Erta'Ale analyses. ${ }^{\dagger}$ May include some $\mathrm{H}_{2} \mathrm{~S}$.

Table 7. Analyses of fumarole gases from Showa-Shinzan, Japan (vol.-\% totaled to 100\%), in connection with a dacite dome [9]. The "active" gases include all gases, other than $\mathrm{H}_{2} \mathrm{O}$, air, excess $\mathrm{N}_{2}$, and the inert gases. The figures for the active gases are volume percent, recomputed to total $100 \%$. The last three lines of the table give the total of the active gases, excess $\mathrm{N}_{2}$ and $\mathrm{H}_{2} \mathrm{O}$, also in volume percent and totaled to $100 \%$

\begin{tabular}{|c|c|c|c|c|c|c|c|}
\hline & & & Temp & re. ${ }^{\circ} \mathrm{C}$ & & & \\
\hline & & 750 & 700 & 645 & 464 & 328 & 194 \\
\hline & $\mathrm{CO}_{2}$ & 65.0 & 61.1 & 64.3 & 91.1 & 89.5 & 76.4 \\
\hline & $\mathrm{CH}_{4}$ & 0.08 & 0.14 & 0.14 & 0.14 & 0.15 & 0.16 \\
\hline & $\mathrm{NH}_{3}$ & 0.06 & 0.007 & 0.01 & 0.10 & 0.007 & 0.01 \\
\hline & $\mathrm{H}_{2}$ & 25.0 & 24.5 & 21.3 & 5.12 & 6.96 & 13.6 \\
\hline $\begin{array}{l}\mathscr{D} \\
\tilde{z}\end{array}$ & $\mathrm{HCl}$ & 5.39 & 8.61 & 8.61 & 1.51 & 1.48 & 4.66 \\
\hline$\hat{2}$ & $\mathrm{HF}$ & 2.76 & 3.54 & 3.51 & 0.88 & 0.65 & 0.43 \\
\hline$\underbrace{4}_{5}$ & $\mathrm{H}_{2} \mathrm{~S}$ & 0.10 & 0.62 & 0.53 & 1.07 & 1.05 & 4.27 \\
\hline & $\mathrm{SO}_{2}$ & 1.66 & 1.50 & 1.60 & 0.12 & 0.14 & 0.50 \\
\hline & Total acti & & & & & & \\
\hline & Gases & 0.723 & 0.592 & 0.569 & 0.859 & 0.948 & 0.258 \\
\hline & $\mathrm{N}_{2}$ & 0.026 & 0.019 & 0.021 & 0.042 & 0.052 & 0.026 \\
\hline & $\mathrm{H}_{2} \mathrm{O}$ & 99.25 & 99.39 & 99.41 & 99.10 & 99.00 & 99.72 \\
\hline
\end{tabular}

SBs indicating an average of one MFS/SB per 4 Ma. The total time comprises 6 major impacts, 4 mass extinctions and 10 - 13 marine black shale ingressions 
(MFSs) on the Arabian Platform [31].

\section{Positive correlations are generally given by:}

Main SBs to both formation b. and mass extinctions.

The SBs-cycles/MFSs-cycles occurred in fairly regular time-spans.

Interplay of major impacts, hot spot activity (Tristan da Cunha), beginning opening of the South Atlantic with northward motion of the African Plate, and mountain building in the collision zone of the latter with Eurasia.

Tremendous volcanic/hot spot activity along the South Atlantic Rift zone, varying global change of atmospheric chemistry caused by both major impacts and super-volcanism and accompanied by cyclic acidic "sturz rain" that had influence on the qualitative/quantitative composition of the Early Cretaceous sediments and rocks (quartz arenites) and on cyclic transport energy (regular fining upward sequences owning lag deposits).

Taking into account all results of this paper, there is to state-accepting a certain scope of analytical error-a high coincidence of the parameters applied and a high probability of more or less global influence by major impacts and super-volcanism induced change of atmospheric chemistry, plate motion and relating mountain building (i.e. Inner Hellenic Suture/Greece), mass extinction and sea level fluctuation (SBs, MFSs). Furthermore, the fining up ward cycles through the Disi F. and the Early Cretaceous F. challenges to verify the interdependence of the processes dealt with.

\section{Closing Statement}

The results submitted in this paper allow putting, finally, some relating questions:

May cyclic fining upward sequences of quartz arenites be originated by hazardous atmospheric chemical processes (acidic "sturz rain events") that have been initiated by so-called "rare events" like major impacts and/or plume-volcanism?

May major impacts trigger a plume/super-plume?

With regard to the fact that hot spots may produce $>20 \mathrm{~km}^{3}$ lava and gas per year which would be comparable with basalt lava effusion along Mid-Oceanic Ridges [28], is there any verified significant influence on climate change and consequences for the further course of Earth History? [Compare: 61 and 62].

Example: the Cretaceous interval 115 - $90 \mathrm{Ma}$ was the warmest period since Precambrian possibly caused by an immense outflow of basaltic lava and gas produced by a super-plume (several hot spots active during the same time-span), [28] [63]: Sea level rise: up to $250 \mathrm{~m}$.

By the way: in Jordan the transition zone Albian/Cenomanian reveals a continuous facies change ranging from fluvial quartz arenite to arenaceous glaucony-bearing dolostone and marly dolomite indicating by lithofacies and ichnofossils the beginning of a warmer climate in an intertidal environment (MFS K 120). K-Ar dating yields under best preservation conditions a radiometric age of the glauconies of $96.1 \pm 1.1 \mathrm{Ma}$ (GMU = glaucony marker unit). Hitherto, the 
GMU controversaries varied between Uppermost Albian and Lowermost Cenomanian [64].

According to GTS 2004 [30] [31] GMU definitely represents the Cenomanian base since the Albian/Cenomanian b. owns an age of 99.6 Ma.

- Is there a direct effect of cyclic super plume activity on cyclic MFSs/SBs by the gigantic lava outflow on ocean floor and by increasing heat flow with regard to sea level rise? (Replacement and volume increase by warming up of seawater!) (see [28] [63]).

- Has a dramatic change of atmospheric chemistry and linked climate, caused merely by a plume/super-plume volcanism, the capacity to generate a major mass extinction like in the case of the Siberian flood basalts at the Permian/Triassic b.? ( 60\%) Yes, it has (see [65] [66] [67]). Thus, without verification of crater and/or shocked fall out back the cause of mass extinction throughout the early Paleozoic remains open.

- Are the results of this paper convincing enough to follow the "95\%-Confidence Line" generally accepted in Science? [68].

"HOT SPOTS" from other "BOUNDARIES":

"And if you would tie hundred knots—-the cord remains one" (Rumi, in [69])

"Words you use for denotation of states signify only approach" (Kalabadhi in [69])

"A scientist with an open mind, who can question the present knowledge of science, will have more of a chance of discovering a higher truth.

A Buddhist in her quest for higher understanding also has to question her present views concerning reality. The technique of understanding is to overcome views and knowledge. The way of non-attachment from views is the basic teaching of Buddhism concerning understanding." (Thich Nhat Hanh, [70]).

\section{Supplement to Abstract}

The results speak for themselves accepting the analytical error scope:

\section{EARLY PALEOZOIC:}

- Chronostratigraphic and lithostratigraphic b. widely coincide with sequence-analytical patterns (SBs, MFSs):

$513 \mathrm{Ma}, 501 \mathrm{Ma}$ ?, $488 \mathrm{Ma}, 483 \mathrm{Ma}, 470 \mathrm{Ma}$ ?, 460.9 - 455.4 Ma.

- Impact events correlate with chronostratigraphic b.:

513/514 Ma, 501/502 Ma, 526.5Ma, 460/455.4, 456 Ma

- Mass extinctions correlate with impact events:

550 Ma: 20\%, 526.5 Ma: 33\%, 514 Ma: 38\%, 502 Ma: 32\%

EARLY CRETACEOUS:

- Temporal coincidence of the Tristan da Cunha Hot Spot-Event (Paraña/Etendeka Flood B, (137 - $127 \mathrm{Ma})) \rightarrow$ track change of South America $(135.1 \mathrm{Ma}) \rightarrow$ northward drifting of the African Plate $\rightarrow$ collision with Eurasia Inner Hellenic Suture since $140 \mathrm{Ma}$, paleosol f., and volcanism in the Levant (145.5 - 136.4 Ma). 
- Global mass extinctions correlate with formation b.

145.5 Ma $(13 \%)=\mathrm{J} / \mathrm{Kb}$., 138/137 Ma $(7 \%)=$ onset of Paraña volcanism followed by SB on the Arabian Platform, 136.4 Ma = Val./Haut. b.Impact: $128 \mathrm{Ma}$ (12\%), $113 \mathrm{Ma}(13 \%)=\mathrm{SB}, \mathrm{Apt} /$ Alb b., $90 \mathrm{Ma}(15 \%)=\mathrm{Alb} / \mathrm{Cen} . \mathrm{b}$.

- Correlation of SBs with Formation b. and mass extinction

- SBs/MFSs-cycles in regular time intervals, each 12 cycles through $45 \mathrm{Ma}$ (one fining upward sequence $\sim 4 \mathrm{Ma}$ ) on the Arabian Platform. Relate these patterns to hazardous "sturz rain" events of high acidity directed by the super plume volcanism during the opening of the South Atlantic! And therefore, comparable with the indirect effects of major impacting volcanism during the Early Paleozoic!

The high temporal coincidence of the interdisciplinary geoscientific patterns applied, make obvious that extraterrestrial and super-volcanic processes may have more influence on sedimentary rock formation as hitherto thought.

\section{Acknowledgements}

This paper comprises research work carried through the last 40 years in Jordan, finally initiated by the discovery of the impact crater Jebel Waqf as Suwwan, Jordan.

The results relate to an intensive and efficient cooperation with colleagues of the Department of Geology, Jordan University, Amman, the Natural Resources Authority (NRA) of Jordan, and the former Department of Geosciences, Braunschweig Technical University, Germany.

We are grateful for financial and technical support provided by the Deutsche For-schungsgemeinschaft (DFG), Deutscher Akademischer Austauschdienst (DAAD) and by the Jordan University, Amman.

The manifold sedimentologic field campaigns were mainly conducted with B.S, Amireh who received his (PhD) from Braunschweig Technical University, A.M. Abed, Fawzy Naji, H. Khoury, E. Salameh, and W. Schneider, not to forget many drivers throughout several decades.

The NRA-Colleagues contributed a mass of sedimentologic data by their mapping work and several constructive publications concerning the Early Paleozoic Sedimentology.

Our papers of the last years published in this Journal wouldn't be written without the fascinating book of N.J. Price "Major Impacts and Plate Tectonics". He has built an inviting bridge to us Sedimentary Geologists for developing interdisciplinary ideas and concepts.

B.U. Haq and A.M, Al-Qahtani established a Cycle Chart of the Arabian Platform that provides an excellent temporal framework and base for manifold correlations of chronostratigraphic, lithostratigraphic, sequence-analytical date, major impact events, and mass extinctions throughout the Paleozoic and Lower Cretaceous between the Arabian-Nubian Shield and the Tethys seaway.

Thus, thanks to all who cooperated with us, including many Bedouins and 
villagers across wide realms of Jordan in this unforgettable project touching $\mathrm{Na}$ ture, Science, Culture, and Society of Jordan.

\section{Conflicts of Interest}

The authors declare no conflicts of interest regarding the publication of this paper.

\section{References}

[1] Schindewolf, O.H. (1963) Neocatastrophism? Zeitschrift der Deutschen Geologischen Gesellschaft, 114, 430-445.

[2] Andel, T.H.V. (1959) Reflections on the Interpretation of Heavy Mineral Analyses. Journal of Sedimentary Research, 29, 153-163. https://doi.org/10.1306/74D708B7-2B21-11D7-8648000102C1865D

[3] Pettijohn, F.J. (1975) Sedimentary Rocks (Vol. 3). Harper and Row, New York, 628 p.

[4] Mack, G.H. (1984) Explanations to the Relationship between Plate Tectonics and Sandstone Composition. Journal of Sedimentary Research, 54, 212-220. https://doi.org/10.1306/212F83E6-2B24-11D7-8648000102C1865D

[5] Amireh, B.S. (1991) Mineral Composition of the Cambrian-Cretaceous Nubian Series of Jordan: Provenance, Tectonic Setting and Climatological Implications. Sedimentary Geology, 71, 99-119. https://doi.org/10.1016/0037-0738(91)90009-3

[6] Troeger, W.E. (1969) Optische Bestimmung der Gesteinsbildenden Minerale, Teil 2 Textband. $822 \mathrm{p}$.

[7] Engelhardt, W.V. (1977) The Origin of Sediments and Sedimentary Rocks. Part III, Sedimentary Petrology. Wiley, New York, 359 p.

[8] Millot, G. (1970) Geology of Clays: Weathering, Sedimentology, Geochemistry. Springer, Berlin, 425 p. https://doi.org/10.1007/978-3-662-41609-9

[9] Krauskopf, K.B. (1982) Introduction to Geochemistry. McGraw-Hill International Series, London, 617 p.

[10] Nickel, E. (1973) Experimental Dissolution of Light and Heavy Minerals in Comparison with Weathering and Intrastratel Solution. In: Stability of Heavy Minerals, Contributions to Sedimentology, Vol. 1, E. Schweizerbart, Stuttgart, 68 p.

[11] Füchtbauer, H. and Schmincke, H.U. (1974) Sediments and Sedimentary Rocks. Part II, Sedimentary Petrology. Wiley, New York, 464 p.

[12] Moraes, M.A. (1989) Diagenetic Evolution of Cretaceous-Tertiary Turbidite Reservoirs, Campos Basin, Brazil. AAPG Bulletin, 73, 598-612. https://doi.org/10.1306/44B4A235-170A-11D7-8645000102C1865D

[13] Girard, J., Savin, S.M. and Aronson, J.L. (1989) Diagenesis of the Lower Cretaceous Arkoses of the Angola Margin: Petrologic, K/Ar Dating and ${ }^{18} \mathrm{O} /{ }^{16} 0$ Evidence. Journal of Sedimentary Petrology, 59, 519-538.

[14] Amireh, B.S., Schneider, W. and Abed, A.M. (1994) Diagenesis and Burial History of the Cambrian-Cretaceous Sandstone Series in Jordan. Neues Jahrbuch für Geologie und Paläontologie-Abhandlungen, 192, 151-182.

[15] Crutzen, P.J. (1987) Acid Rain at the K/T Boundary. Nature, 330, 108. https://doi.org/10.1038/330108a0

[16] Zahnle, K.J. (1990) Atmospheric Chemistry by Large Impacts. In: Global Catastro- 
phes in Earth History, Geol. Soc. America, Spec. Pap., Vol. 247, 271-288. https://doi.org/10.1130/SPE247-p271

[17] Stöffler, D. (2002) Bedrohung aus dem Weltall-Asteroiden und Kometen. An den Fronten der Forschung. Kosmos-Erde-Leben. Verhandlungen der Gesellschaft Deutscher Naturforscher und Ärzte, Vol. 122, 81-97.

[18] Koch, H.P. (2000) The Diluvian Impact: The Great Flood Catastrophe 10,000 Years Ago as the Consequence of a Comet's Impact. Peter Lang Pub Incorporated, Europ. Verlag der Wissensch., Wien, New York, 27/4 p.

[19] Smit, J. (1999) The Global Stratigraphy of the Cretaceous/Tertiary Boundary Impact Ejecta. Annual Reviews of Earth and Planetary Science, 27, 75-113. https://doi.org/10.1146/annurev.earth.27.1.75

[20] Stöffler, D. (1971) Coesite and Stishovite in Shocked Crystalline Rocks. Journal of Geophysical Research, 76, 5474-5488. https://doi.org/10.1029/JB076i023p05474

[21] Ramme, G. (1982) Sedimentologische Untersuchungen an tertiären Sanden (Meanwhile Corrected to Upper Maastrichtian) im Bereich des Dorm/Norddeutschland, Dipl. Thesis, Braunschweig Technical University, 138 p.

[22] Schneider, W. and Salameh, E. (2018) How to Trace out Impact-Triggered Effects Globally Scattered around Formation Boundaries: Case Uhry, North Germany (Eocene/Oligocene Boundary). Open Journal of Geology, 8, 9-32. https://doi.org/10.4236/ojg.2018.81002

[23] Price, N.J. (2001) Major Impacts and Plate Tectonics. Routledge, London, 354 p. https://doi.org/10.1201/9780203165454

[24] Schneider, W. and Salameh, E. (2012) Did Major Impacts Affect Sedimentologic/Sequence-Analytical Pattern of the Early Palaeozoic Sedimentary Systems of Jordan, Arabian Plate? Open Journal of Geology, 2, 241-252. https://doi.org/10.4236/ojg.2012.24024

[25] Husseini, M.I. (1988) The Arabian Infracambrian Extensional System. Tectonophysics, 148, 93-103. https://doi.org/10.1016/0040-1951(88)90163-1

[26] Husseini, M.I. (1989) Tectonic and Deposition Model of Late Precambrian-Cambrian Arabian and Adjoining Plates. AAPG Bulletin, 73, 1117-1131. https://doi.org/10.1306/44B4A54B-170A-11D7-8645000102C1865D

[27] Al-Husseini, M.I. (2000) Origin of the Arabian Plate Structures: Amar Collision and Najd Rift. GeoArabia, 5, 527-542.

[28] Frisch, W. and Meschede, M. (2009) Plattentektonik. 3. Aufl., Primus Verlag, Darmstadt, $196 \mathrm{p}$.

[29] Geert, K., Afifi, A.M., Al-Hajri, S.I.A. and Droste, H.J. (2001) Paleozoic Stratigraphy and Hydrocarbon Habitat of the Arabian Plate. GeoArabia, 6, 407-442.

[30] Sharland, P.R., Archer, R., Casey, D.M., Davies, R.B., Hall, S.H., Heward, A.P., Horbury, A.D. and Simmons, M.D. (2001) Arabian Plate Sequence Stratigraphy. Geo Arabia Special Publication 2, Gulf PetroLink, Bahrain, 371 p.

[31] Haq, B.U. and Al-Qahtani, A.M. (2005) Phanerozoic Cycles of Sea-Level Change on the Arabian Platform. GeoArabia, 10, 127-160.

[32] Schneider, W., Amireh, B.S. and Abed, A.M. (2007) Sequence Analysis of the Early Paleozoic Sedimentary Systems of Jordan [Sequenzanalyse der aAtpaläozoischen Sedimentären Gesteinsserien Jordaniens]. Zeitschrift der deutschen Gesellschaft für Geowissenschaften, 158, 225-247. https://doi.org/10.1127/1860-1804/2007/0158-0225

[33] Jarrar, G.H. (1986) Late Proterozoic Crustal Evolution of the Arabian-Nubian-Shield 
in the Wadi Araba Area, SW-Jordan. Geologisches Jahrbuch Reihe B, Band B 61, E. Schweizerbart, Stuttgart, 3-87.

[34] Jarrar, G., Wachendorf, H. and Zellmer, H. (1991) The Saramuj Conglomerate: Evolution of a Pan-African Molasse Sequence from Southwest Jordan. N. Jb. Geol. Palaontol. Mh 6, 335-356.

[35] Jarrar, G., Wachendorf, H. and Saffarini, G. (1992) A Late Proterozoic Bimodal Volcanic/Subvolcanic Suite from Wadi Araba, Southwest Jordan. Precambrian Research, 56, 51-72. https://doi.org/10.1016/0301-9268(92)90083-Z

[36] Amireh, B.S., Schneider, W. and Abed, A.M. (1994) Evolving Fluvial-Transitional-Marine Deposition through the Cambrian Sequence of Jordan. Sedimentary Geology, 89, 65-90. https://doi.org/10.1016/0037-0738(94)90084-1

[37] Makhlouf, I.M. and Abed, A.M. (1991) Depositional Facies and Environments in the Umm Ishrin Sandstone Formation, Dead Sea Area, Jordan. Sedimentary Geology, 71, 177-187. https://doi.org/10.1016/0037-0738(91)90100-R

[38] Amireh, B.S., Schneider, W. and Abed, A.M. (2001) Fluvial-Shallow Marine-Glaciofluvial Depositional Environments of the Ordovician System in Jordan. Journal of Asian Earth Sciences, 19, 45-60. https://doi.org/10.1016/S1367-9120(00)00010-9

[39] Seilacher, A. (1992) An Updated Cruziana Stratigraphy of Gondwanan Palaeozoic sandstones. The Geology of Libya, 4, 1565-1581.

[40] Seilacher, A. (1994) How Valid Is Cruziana Stratigraphy? Geologische Rundschau, 83, 752-758. https://doi.org/10.1007/BF00251073

[41] Amireh, B.S. (1997) Sedimentology and Palaeogeography of the Regressive-Transgressive Kurnub Group (Early Cretaceous) of Jordan. Sedimentary Geology, 112, 69-88. https://doi.org/10.1016/S0037-0738(97)00024-9

[42] Garfunkel, Z. and Derin, B. (1988) Reevaluation of Latest Jurassic-Early Cretaceous History of the Negev and the Role of Magmatic Activity. Israel Journal of Earth-Sciences, 37, 43-52.

[43] Rampino, M.R. (1994) Extraterrestrial Impacts and Mass Extinctions of Life. In: Gehrels, T., Ed., Hazards Due to Comets \& Asteroids, Univ. of Arizona Press, Tucson, 827-857.

[44] Emiliani, C. (1992) Planet Earth: Cosmology, Geology, and the Evolution of Life and Environment. Cambridge University Press, Cambridge.

[45] Pan Terra Inc. (2002) A Correlated History of Earth. 3rd Edition, Copyright Pan Terra Inc., Hill City.

[46] Grieve, R.A. and Shoemaker, E.M. (1994) The Record of Past Impacts on Earth. In: Gehrels, T., Ed., Hazards Due to Comets and Asteroids, Univ. of Arizona Press, Tucson, 417-462.

[47] Amireh, B.S. (1987) Sedimentological and Petrological Interplays of the Nubian Series in Jordan with Regard to Paleogeography and Diagenesis. Doctoral Dissertation, Technische Universität Carolo Wilhelmina zu Braunschweig, Geol. Palaont. Diss., 7, 232 p., 33 Fig., 6 Tables, 16 Plates.

[48] Folk, R.L. and Ward, W.C. (1957) Brazos River Bar [Texas]; a Study in the Significance of Grain Size Parameters. Journal of Sedimentary Research, 27, 3-26. https://doi.org/10.1306/74D70646-2B21-11D7-8648000102C1865D

[49] Miall, D. (1996) The Geology of Fluvial Deposits. Springer-Verlag, Berlin, Heidelberg, New York, $582 \mathrm{p}$. 
[50] Schneider, W., Abed, A.M. and Salameh, E. (1984) Mineral Content and Diagenetic Pattern-Useful Tools for Lithostratigraphic Subdivision and Correlation of the $\mathrm{Nu}$ bian Series: Results of Work in the Wadi Zerqa Ma'in Area, Jordan. Schweizerbart'sche Verlagsbuchhandlung. Geol. Jb. B 53, 55-75.

[51] Burgath, K.P., Hagen, D. and Siewers, U. (1984) Geochemistry, Geology, and Primary Copper Mineralization in Wadi Araba, Jordan. Hannover, Geol. Jb., B 53, 3-53.

[52] Heitkemper, H. (1988) Kupfervererzungen in Kambrischen Sedimenten des Feinan-Gebiets, SW-Jordanian. Dipl. Thesis, Ruhr Universitat Bochum, 61 p.

[53] Jacobshagen, V. (1994) Orogenic Evolution of the Hellenides: New Aspects. In: Active Continental Margins-Present and Past, Geol. Rundschau 83, Springer, Berlin, 249-256. https://doi.org/10.1007/978-3-662-38521-0_4

[54] Schneider, W., Bode, St. and Oppermann, A. (1988) Zusammenhänge Zwischen Deckenvorschub, Suturprogadation, Erosion und Flysch-Zusammensetzung in den Helleniden. N. Jb. Geol. Palaont. Abh., 209, 349-379.

[55] Amireh, B.S. (1994) Heavy and Clay Minerals as Tools in Solving Stratigtaphic Problems: A Case Study from the Disi Sandstone (Early Ordovician) and the Kurnub Sandstone (Early Cretaceous) of Jordan. N. Geol. Paläont. Mh., 4, 205-222.

[56] Vail, P.R., et al. (1991) The Stratigraphic Signatures of Tectonics, Eustacy and Sedimentology: An Overview. In: Eisele, G., Rieken, W. and Seilacher, A., Eds., Cycles and Events in Stratigraphy, Springer, Berlin, 617-659.

[57] Galloway, W.E. (1989) Genetic Stratigraphic Sequences in Basin Analysis I: Architecture and Genesis of Flooding-Surface Bounded Depositional Units. AAPG Bulletin, 73, 125-142. https://doi.org/10.1306/703C9AF5-1707-11D7-8645000102C1865D

[58] Lopatin, N.V. (1971) Temperatura Geologicheskoye Vema Kak Faktory. Uglefikatsii, (Temperature and Geologic Time as Factors in Coalification). Akad, Nauk SSSR, IZV, Ser. Geol, 3, 95-106.

[59] Turner, S., Regelous, M., Simon Kelley, S., Hawkesworth, C. and Mantovanib, M. (1994) Magmatism and Continental Break-Up in the South Atlantic: High Precision 40Ar-39Ar Geochronology. Earth and Planetary Science Letters, 121, 333-348. https://doi.org/10.1016/0012-821X(94)90076-0

[60] Wilson, M. (1992) Magmatism and Continental Rifting during the Opening of the South Atlantic Ocean: A Consequence of Lower Cretaceous Super-Plume Activity? Geological Society, London, Special Publications, 68, 241-255. https://doi.org/10.1144/GSL.SP.1992.068.01.15

[61] Schneider, W. and Salameh, E. (2015) The Last 15,000 Years: Climate-Controlled and "Rare-Event"-Triggered/Rise and Fall of Holocene Cultures in the Near/Middle East and in Central Europe-Evidence and Background. Open Journal of Geology, 5, 743. https://doi.org/10.4236/ojg.2015.511065

[62] Schneider, W. and Salameh, E. (2018) Historical Course Follows Climate Change: Patterns of the Northern Hemisphere-From Peoples' Migration until the Industrial Revolution (3rd-18th Century). Open Journal of Geology, 8, 1167-1194. https://doi.org/10.4236/ojg.2018.813071

[63] Larson, R.L. (1995) Die Superplume-Episode in der Mittleren Kreidezeit. Spektrum der Wissenschaft, 7, 48-52.

[64] Amireh, B.S., Jarrar, G., Henjes-Kunst, F. and Schneider, W. (1998) K-Ar Dating, X-Ray Diffractometry, Optical and Scanning Electron Microscopy of Glauconies from the Early Cretaceous Kurnub Group of Jordan. Geological Journal, 33, 49-65. https://doi.org/10.1002/(SICI)1099-1034(199801/03)33:1<49::AID-GJ759>3.0.CO;2$\underline{\mathrm{Y}}$ 
[65] White, R.W. and Saunders, A.D. (2005) Volcanism, Impact and Massextinction: Incredible or Credible Coincidences? Lithos, 79, 299-316.

https://doi.org/10.1016/j.lithos.2004.09.016

[66] Peterson, S.V., Dutton, A. and Lohman, K.C. (2016) End-Cretaceous Extinction in Antarctica Linked to Both Daccan Volcanism and Meteoritic Impact via Climate Change. Nature Communications, 7, Article ID: 123079.

https://doi.org/10.1038/ncomms12079

[67] Sigl, M., Winstrup, M., Mc Conell, J.R., Welton, K.C., Plunket, G., Ludlow, F. and Fischer, H. (2015) Timing and Climate Forcing of Volcanic Eruptions for the Past 2500 Years. Nature, 523, 543-549. https://doi.org/10.1038/nature14565

[68] Oreskes, N. and Conway, E.M. (2015) Vom Ende der Welt. Chronik eines Angekündigten Unterganges. Oekom Verlag, München, $121 \mathrm{p}$.

[69] Shah, I. (2002) Die Sufis-Botschaft der Derwische, Weisheit der Magier, Diederichs Gelbe Reihe, 2. Auflage, München, 317 p.

[70] Hahn, T.N. (1996) Being Peace. Parallax Press, Berkley, 118 p. 